\title{
Probable palaeogeographic influences of the Lower Cretaceous Iberian rifting phase in the Eastern Cameros Basin (Spain) on dinosaur trackway orientations
}

\author{
J.J. Moratalla ${ }^{a, *}$, J. Hernán ${ }^{b, c}$ \\ a Instituto Geológico y Minero de España (Museo Geominero), Ríos Rosas 23, 28003 Madrid, Spain \\ ${ }^{\mathrm{b}}$ Escuela Técnica Superior de Ingenieros de Minas de Madrid, Universidad Politécnica de Madrid, Ríos Rosas 21, 28003 Madrid, Spain \\ c Dpto de Petrología y Geoquímica, Universidad Complutense de Madrid-Instituto de Geología Económica CSIC, José Antonio Novais 2, 28040 Madrid, Spain
}

\section{A R T I C L E I N F O}

\section{Article history:}

Received 14 January 2010

Received in revised form 10 May 2010

Accepted 25 May 2010

Available online 4 June 2010

\section{Keywords:}

Palaeoichnology

Dinosaurs

Trackways

Palaeogeography

Cretaceous

Cameros Basin

Spain

\begin{abstract}
A B S T R A C T
The Cameros Basin sedimentary infill comprises a large, essentially continental, megasequence ranging from the Tithonian (Upper Jurassic) to the Albian (Lower Cretaceous). It occupies an area of some $5500 \mathrm{~km}^{2}$, and is home to around 300 dinosaur tracksites. Most of these tracksites are found in either the Huérteles Formation, which is part of the Oncala Group (Berriasian), or the Enciso Group (Lower Aptian), both of which represent early Cretaceous lacustrine episodes. Dinosaur trackways $(n=1170)$ from both episodes were analysed in order to establish the preferred direction of dinosaur movement, and to determine whether these movements were influenced by the palaeogeographic and palaeoenvironmental conditions of the area.

The Huérteles Formation is interpreted as a complex record of alluvial plain systems distally connected with a playa-lake. Its dinosaur tracksites are distributed throughout its alluvial plain facies and trackways show two preferential unidirectional orientations: 1) NW, more or less parallel to the distribution of the facies belt and 2) NNE. The Enciso Group is represented by a wide and shallow lacustrine system connected with marine environments towards the SE (Iberian Basin realm) and in close proximity to marine settings to the NW (Basque-Cantabrian Basin realm), rendering the Cameros Basin as the only continental connection between the Ebro and Iberian Massifs. The fluctuating (but always shallow) water level of the system with frequent desiccations probably allowed dinosaurs to pass through the lake basin. As a consequence of these paleogeographic restrictions, the dinosaur trackways generally show a bidirectional NE-SW orientation. Despite the temporal and geographical differences between the Huérteles Formation and Enciso Group, the ichnocenoses of both are dominated by theropod dinosaur trackways ( $85 \%$ as a mean value). This is probably explained by these dinosaurs being more active than others, a consequence of their searching/hunting behaviour.
\end{abstract}

(c) 2010 Elsevier B.V. All rights reserved.

\section{Introduction}

The first Cameros Basin dinosaur tracksite was reported by Casanovas and Santafé in 1971. Since then many more such reports have been published and the literature is now rich in footprint data for this region (Moratalla and Sanz, 1997; Moratalla et al., 1997a; PérezLorente, 2002, 2003 and references therein). Some 300 tracksites are now known, but every year new discoveries are made, confirming the importance of this area for the study of fossil vertebrate ichnology.

The preferred directions taken by the makers of these trackways have, however, been the focus of few studies (Martín-Escorza, 1986, 1988,2001 ), and the mixing of individual footprint and trackway data from formations of different age render the results obtained difficult to interpret. The present paper tries to throw more light on this topic

\footnotetext{
* Corresponding author.

E-mail address: j.moratalla@igme.es (J.J. Moratalla).
}

by examining the orientations of entire trackways associated with well-differentiated stratigraphic units.

The relationship between the preferential orientations of dinosaur trackways and palaeoenvironmental conditions has been an important area of study in dinosaur ichnology (Lockley, 1986; Lockley and Conrad, 1989; Lockley, 1991; Lockley and Hunt, 1995). The phenomenon of regionally extensive, but stratigraphically-restricted, track-bearing layers, or megatracksites (Lockley and Pittman, 1989) or "dinosaur freeways" was first noted in Jurassic and Cretaceous coastal plain deposits in the United States (Lockley and Pittman, 1989; Lockley, 1997) and Europe (Meyer, 1993). A megatracksite (sensu Lockley and Pittman, 1989) is a large, track-bearing layer (single surface of thin unit) covering a wide area, perhaps even hundreds to thousands of square kilometres. The Moab megatracksite in Utah (Lockley, 1991), the Glen Rose Formation in Texas (Bird, 1944; Langston, 1979; Farlow et al., 2006), the Dakota Sandstone (Gillette and Thomas, 1985; Lockley, 1985, 1987; Lockley et al., 1992; Matsukawa et al., 1999; Schumacher, 2003; Lockley et al., 2006b) and the Solothurn Limestone of Switzerland (Meyer, 1993) are outstanding examples. Lacustrine regions with track-bearing layers 
covering a relatively small area but spanning a relatively long period of time represent another palaeoenvironment providing large accumulations of dinosaur tracksites. Abundant examples of lacustrine systems with rich dinosaur ichnofaunas have been identified for the Mesozoic ranging from the: (1) Triassic, e.g., the Fleming Fjord Formation (Jenkins et al., 1994; Milàn et al., 2004) and Chinle Group (Gaston et al., 2003), through the (2) Jurassic, e.g., the Whitmore Point Member of the Moenave Formation (Milner et al., 2006), the Morrison Formation (Lockley et al., 1998), and the East Berlin Formation (Getty, 2005), to the (3) Cretaceous, e.g., the Sousa Formation (Leonardi, 1994; Leonardi and Dos Santos, 2004), the Jindong Formation (Lockley and Matsukawa, 1998; Paik et al., 2001; Lockley et al., 2006a), the Uhangi Formation (Huh et al., 2003), the Haman Formation (Huh et al., 2003), and the El Molino Formation (Meyer et al., 2001).

Despite their structural differences, both megatracksites and the latter, vertically extensive, "basinal" track-bearing systems have yielded important clues regarding dinosaur fauna composition, behaviour and movement patterns. The features of ichnocenoses reflect the composition of palaeocommunities and provide testimony to the abundance of dinosaurs over relatively large areas. Dinosaur abundance can be estimated from the number of trackways and the number of tracksites (Lockley, 1997). It should be remembered, however, that ichnocenoses can show bias with respect to animal size, activity rates and preservation potential.

The study of dinosaur trackway orientation patterns has two main aims: 1) to provide information on the relationships between different trackways within the same tracksite, thus yielding information about the behaviour of different individuals, and 2) to determine the general orientation pattern of dinosaur trackways on a regional scale (which implies the analysis of several tracksites) (Moratalla et al., 1997b). The presence of parallel dinosaur trackways can be indicative of gregarious behaviour or the passage of individuals along a physically constrained pathway (Ostrom 1972; Lockley, 1986, 1991). The presence of parallel, bidirectional trackways has long been associated with physical restriction to movement, e.g., walking along the shores of a lake (checked against ripple-mark directions or other indications of shoreline orientation) (Lockley et al., 1986; Lockley, 1987, 1991, 1997). Sometimes, movements appear to be unidirectional, even with regular spacing between the trackways (intertrackway spacing, sensu Lockley, 1989). Such a pattern is usually interpreted as the consequence of gregarious behaviour (Bird, 1944; Ostrom, 1972; Currie and Sarjeant, 1979; Lockley, 1989; Lucas, 1998). These general preferential movements may, however, also have been influenced by palaeogeographic conditions structures at a more regional scale.

The Cameros Basin is in fact a mixture of the two types of extensive track-bearing deposits mentioned above, and has thick sediments (total combined stratigraphic thickness up to $10000 \mathrm{~m}$ ) covering a wide area (about $5500 \mathrm{~km}^{2}$ ) (Moratalla, 2008). However, the frequent lateral change shown by its facies does not allow for track-bearing layers to persist over long distances; the conditions of the megatracksite concept of Lockley and Pittman (1989) are therefore not met. The basin lies in the most northwestern part of the Iberian Range, outcropping into the Spanish provinces of Burgos, Soria and La Rioja (Fig. 1). It can be divided into two sub-basins - the Eastern and Western Cameros - of rather different stratigraphic framework (see General geological setting for further details). The preservation conditions responsible for maintaining the fossil record were different in the two sub-basins. Indeed, the Western Cameros sub-basin is characterized by the predominance of osteological remains (Torcida, 2006), while the Eastern Cameros is characterized by ichnological sites (Moratalla et al., 1997a; Sanz et al., 1997; Pérez-Lorente, 2003; Hernández-Medrano et al., 2005-2006).

The first large stratigraphic study of the region was undertaken in the eastern sector by Tischer (1966), who defined five geological groups: Tera, Oncala, Urbión, Enciso and Oliván, ranging from the Tithonian to the Albian. The Tera, Urbión and Oliván Groups are characterized by fluvio-lacustrine sediments, while both the Oncala and Enciso Groups are dominated by limestones of clearly lacustrine origin. The Tithonian to Albian synrift infill of the Eastern Cameros sub-basin has yielded a significant but irregular record of dinosaur ichnofaunas covering a period of some 42 million years, providing important ichnological evidence of dinosaur activity for most of the early Cretaceous. This record is particularly associated with lacustrine environments such as those of the Huérteles Formation and Enciso Group.

Given the long period of time between the Berriasian (Huérteles Formation) and the Aptian (Enciso Group), it might be expected that many differences should be found between their ichnological records, which would be influenced by their respective palaeogeographic and palaeoenvironmental conditions, sedimentation rates, fauna and flora etc. Dinosaur track morphotypes might, therefore, also differ, as might the general tracksite features. The differences in the palaeogeographic conditions between the Berriasian interval and the Lower Aptian lacustrine episodes were probably great enough that they might easily have had a significant influence on preferential dinosaur movements throughout the entire Cameros area.

The aim of the present paper is to examine the preferential orientations of the dinosaur trackways made during the Berriasian and Aptian, and to attempt to correlate them with the palaeoenvironmental and paleogeographic reconstructions of the basin for these periods. In the study area, two distinct temporal lacustrine episodes and a large number of dinosaur trackways (1170) were analysed. Two original palaeogeographic maps (based on the information available in the literature) corresponding to the age of the units discussed in this paper are presented; they illustrate the close relationship between the palaeogeography and sedimentary environments of these times and the main patterns of dinosaur movement.

\section{General geological setting}

The Cameros Basin is placed in the Cameros structural unit which consists of an intracratonic fold-and-thrust belt with a dominant NWSE orientation, a result of the Palaeogene-Lower Miocene compressional phase (Guimerà et al., 1995). The northern border is a 100 kmlong striking thrust veering from E-W to NW-SE (traditionally known as the Cameros or North Cameros thrust) over the Tertiary Ebro Basin. The southern margin is characterized by NE-SW to NW-SE-oriented folds and thrusts over the Tertiary Duero and Almazán Basins (Fig. 1A). Thus, the Cameros unit has an overall asymmetric pop-up structure and represents the result of the Tertiary inversion of the uppermost Jurassic-early Cretaceous extensional Cameros Basin (Guimerà et al., 1995).

During Mesozoic times the Iberian plate underwent an extensional regime leading to the widespread development of pericratonic rift systems, including the South-Iberian Continental Margin (Vera, 2001), the North Iberian Margin (García-Mondéjar et al., 1996; Vergés and García-Senz, 2001), and the Western Iberian Margin (Pinheiro et al., 1996), as well as intracratonic rifting named the Mesozoic Iberian Rift System (MIRS) or Iberian Basin (Salas et al., 2001). The MIRS comprises four evolutionary stages of the Mesozoic: (a) the Late PermianHettangian rift cycle 1, (b) the Sinemurian-Oxfordian postrift stage 1, (c) the latest Oxfordian-middle Albian rift cycle 2, and (d) the Late Albian-Maastrichtian postrift stage 2. During the onset of the second rifting cycle, which showed a NNE-SSW regional extension related to the opening of the Bay of Biscay and the North Atlantic, four strongly subsiding and well-differentiated sedimentary domains were generated: (1) the Cameros Basin (both Eastern and Western sub-basins), (2) the Maestrazgo Basin, (3) the offshore Columbretes Basin and, (4) the South-Iberian Basin (Salas and Casas, 1993; Salas et al., 2001). Thus, the Cameros Basin is the most interior and northwesterly sedimentary basin of the MIRS. As a result, it differs from the other MIRS basins in that it shows continental infilling with only slight 
A

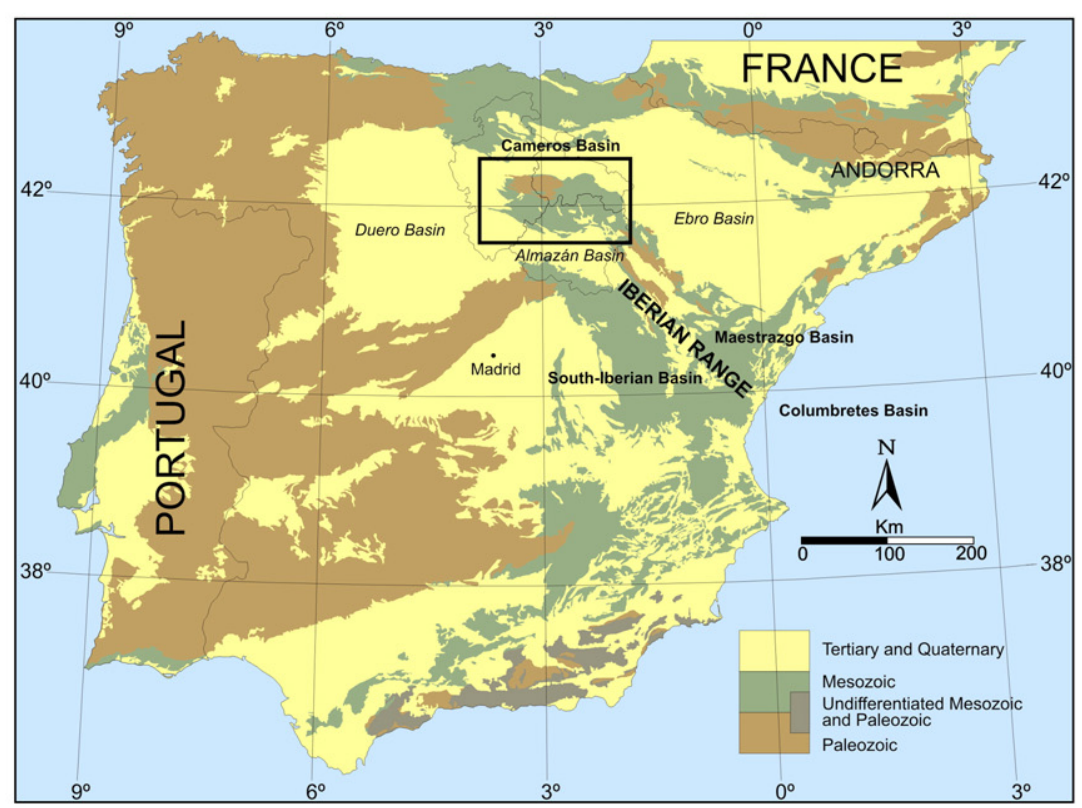

B

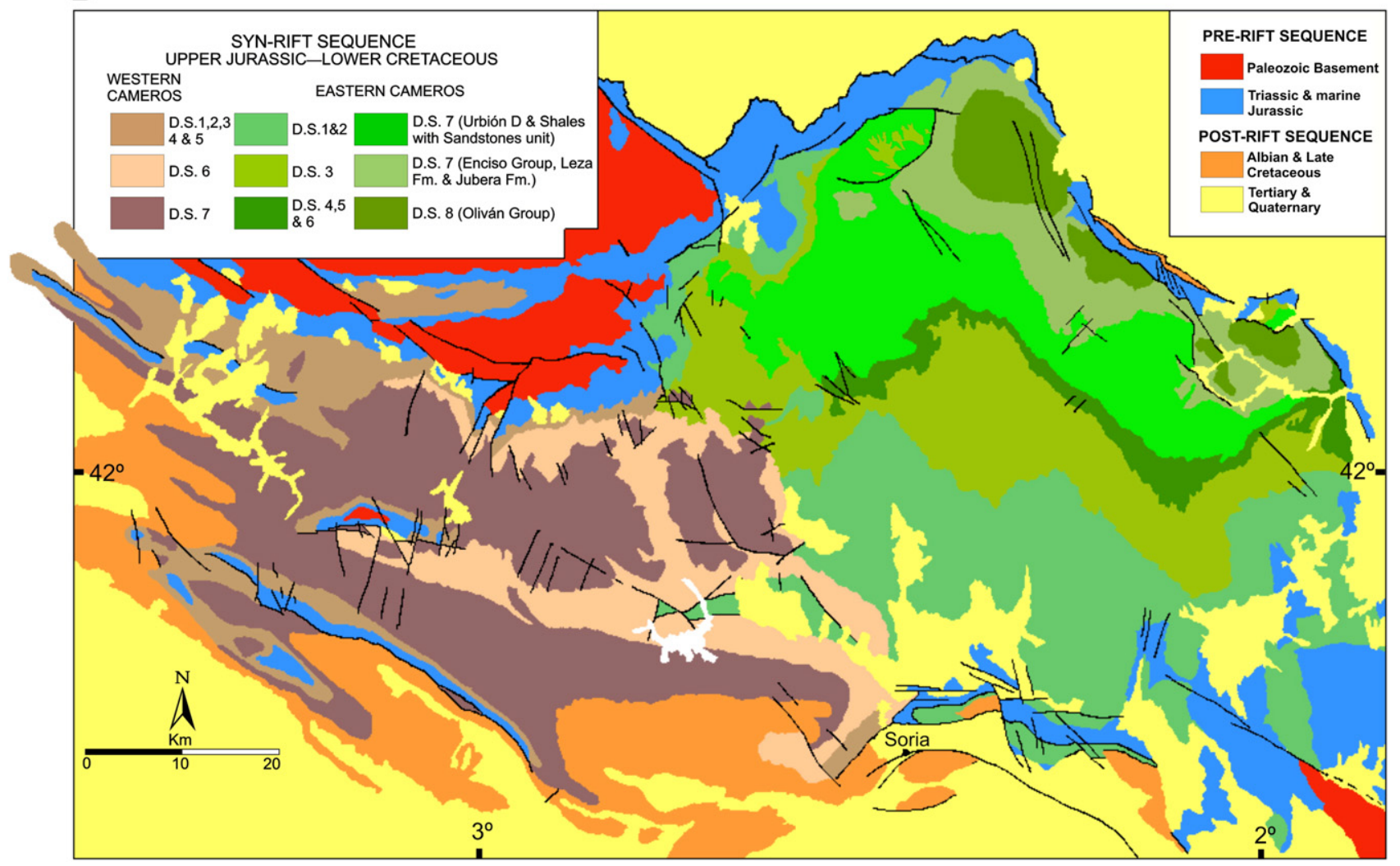

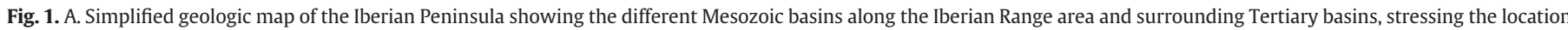
of the Cameros Basin. B. Detailed geological map of the Cameros Basin.

marine influence, a high rate of subsidence and sedimentation, and in that it exhibits a low to very-low grade metamorphism event (Mas et al., 2002).

The Cameros Basin comprises two sub-basins, each of which has a characteristic palaeogeographic and tectonosedimentary setting (Fig. 1B). The Eastern Cameros sub-basin is a $70 \mathrm{~km}-\mathrm{long}$ and $45 \mathrm{~km}-$ wide rectangular sub-basin mainly oriented NW-SE. It comprises up to $10,000 \mathrm{~m}$ of fluvio-lacustrine deposits with minor marine incursions (Salas et al., 2001) and well-preserved ichnological tracksites, mainly dinosaur footprints, although pterosaur, crocodile, bird and turtle tracks have also been found. The Western Cameros sub-basin is another rectangular, roughly W-E-orientated sub-basin some $105 \mathrm{~km}$ long and $50 \mathrm{~km}$ wide and with a maximum thickness of about $3000 \mathrm{~m}$, representing fluvial and lacustrine systems with no known marine incursions (Arribas et al., 2003).

Two major models vie to explain the tectonic rift-basin nature of the Cameros Basin: model 1 involves an extensional-ramp basin formed over a roughly south-dipping ramp in a deep subhorizontal 
extensional fault located in the basement (Mas et al., 1993; Guimerà et al., 1995), while model 2 involves a half-graben basin over a shallow detachment level (Soto et al., 2007) (Type 1 of Withjack et al. (2002)). In fact, both theories agree with a synclinal basin developed over the hanging-wall trough, with no high footwall scarp.

Since the work of Tischer (1966), many stratigraphic studies of the Cameros Basin have been published (Mas et al., 1993, 2002, 2003). The uppermost Jurassic-Early Cretaceous synrift infill, and consists of continental deposits with scarce marine incursions, forms a megasequence bound by two regional unconformities: the bottom one being Tithonian and the upper one intra-Albian in age (Fig. 2). This megasequence, which was deposited over a period of 42 million years (according to the geological time scale of Gradstein et al. (2005)), can be subdivided into eight depositional sequences bounded by intrabasinal unconformities. The sequential arrangement within each depositional sequence (DS) is composed of a siliciclastic-fluvial unit succeeded by a gradual vertical and/or lateral change into a carbonate-lacustrine unit (Salas et al., 2001; Mas et al., 2002). This synrift stratigraphic architecture is well developed in most nonmarine rift basins (Lambiase, 1990; Schlische and Olsen, 1990). Fig. 2 shows the significant development of carbonate lacustrine systems in the southeastern domains of the Cameros basin. DS-1 (Ágreda Formation) is dominated by alluvial deposits in which no dinosaur tracksites are preserved. DS-2 is represented by the fluvial Magaña Formation (with only one tracksite) and the fluvio-lacustrine Sierra Matute Formation (with three tracksites). DS-3 is composed of two fluvio-lacustrine units: the Huerteles Formation (with 56 tracksites although only 35 have been studied in this paper) (Table 1) and the Valdeprado Formation (with 7 tracksites). DS-4, 5 and 6 are formed by fluvial and lacustrine units with no confirmed tracksites (the Urbión B unit in DS-5 may contain some). DS-7 is composed of a fluvial unit named Urbión D which has some 16 tracksites, and the lacustrine Enciso Group, with 103 tracksites (including different levels inside the same tracksite name, see Table 2). The northern border of the Enciso Group comprises the carbonate-lacustrine Leza Formation (with six tracksites). DS-8 consists of the fluvial Oliván Group for which no dinosaur tracksites have been reported in the literature, but which does contain an unknown number. Thus, the Huérteles Formation (DS-3) and the Enciso Group (DS-7) concentrate over 90\% of the Cameros Basin dinosaur tracksites. These last two formations lie within the Eastern Cameros Sub-basin. The Enciso Group comprises the uppermost lithostratigraphic unit of DS-7, whereas the Huérteles Formation forms the lowermost unit of DS-3. Both units are described in more detail below. The track-rich lacustrine episodes of both formations coincide in time with the two pulsating phases of accelerated rifting defined by Mas et al. (1993).

\section{Materials and methods}

Using software to provide an unfolded view of the track-bearing layers, Martín-Escorza (2001) calculated the preferred orientation of the Cameros dinosaur tracks employing orientation data from all the Cameros geological groups. However, these data referred only to individual footprints $(n=962)$. The results were interpreted as showing that the preferential movement of dinosaurs was mainly southward. In the present work, however, entire trackways (although in some cases just two consecutive footprints) were used rather than individual footprints since the orientation of the latter can vary around the mean direction by some $20^{\circ}$ (personal observations). Trackway orientation better reflects the original direction of animal movement,

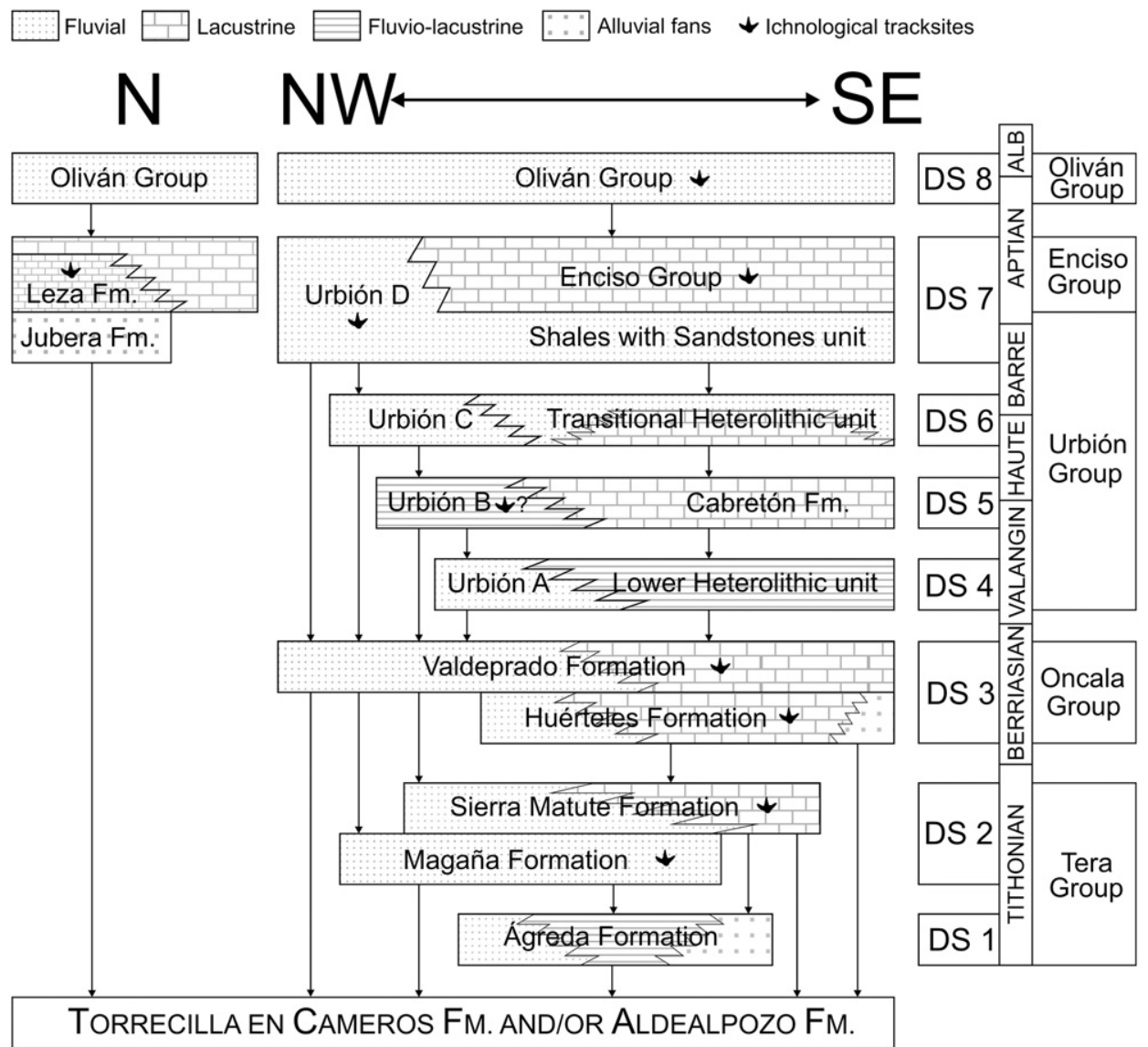

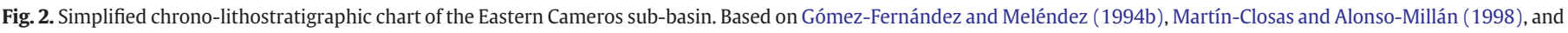

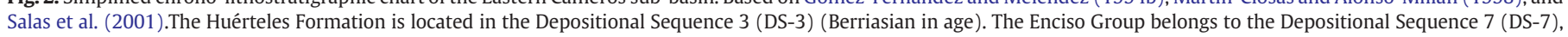
considered as Lower Aptian. Both sedimentary units concentrate the great majority of the Cameros Basin dinosaur tracksites. 
Table 1

Tracksites from the Huérteles Formation (Cameros Basin, Spain).

\begin{tabular}{|c|c|c|c|c|c|c|c|c|}
\hline Area & No. & Tracksite & Locality & No. & Ther & Orn & Sau & Indet \\
\hline \multirow[t]{10}{*}{ Santa Cruz-Bretún } & 29 & Los Tormos A-B & Santa Cruz de Yanguas & 3 & 3 & & & \\
\hline & & Santa Cruz & Santa Cruz de Yanguas & 1 & & 1 & & \\
\hline & & El Prao Caido & Santa Cruz de Yanguas & 14 & 14 & & & \\
\hline & 30 & La Matecasa & Bretún & 1 & 1 & & & \\
\hline & & El Frontal & Bretún & 17 & 17 & & & \\
\hline & & Fuente La Corte A,B and C & Bretún & 15 & 14 & 1 & & \\
\hline & 31 & Santa Cristina & Villar del Río & 5 & 5 & & & \\
\hline & 32 & Serrantes & Villar del Río & 26 & 26 & & & \\
\hline & 33 & Salgar de Sillas & Los Campos & 15 & 14 & & 1 & \\
\hline & & La Revilleja & Los Campos & 1 & & & 1 & \\
\hline \multirow[t]{10}{*}{ San Pedro-Fuentes } & 34 & Valdegén & Villar del Río & 29 & 29 & & & \\
\hline & 35 & Fuentesalvo & Villar del Río & 12 & 12 & & & \\
\hline & 36 & San Roque & Ventosa de San Pedro & 5 & 5 & & & \\
\hline & 37 & El Castillejo 1-5 & Matasejún & 6 & 6 & & & \\
\hline & 38 & Barranco de Valdelavilla I-VII & San Pedro Manrique & 17 & 14 & & 2 & 1 \\
\hline & 39 & Miraflores I-IV & Fuentes de Magaña & 7 & 3 & & 4 & \\
\hline & & Umbría del Sastre & Fuentes de Magaña & 3 & 3 & & & \\
\hline & $*$ & La Hoyuela & Las Fuentes de San Pedro & 1 & & 1 & & \\
\hline & & & Total & 178 & 166 & 3 & 8 & 1 \\
\hline & & & $\%$ & & 93.3 & 1.7 & 4.5 & 0.6 \\
\hline
\end{tabular}

Table 2

Tracksites from the Enciso Group (Cameros Basin, Spain).

\begin{tabular}{|c|c|c|c|c|c|c|c|c|}
\hline Area & No. & Tracksite & Locality & No. & Ther & Orn & Sau & Indet \\
\hline \multirow[t]{15}{*}{ Munilla-Hornillos } & 1 & San Vicente de Robles & San Vicente de Robles & 7 & 5 & 2 & & \\
\hline & 2 & San Martín 1-3 & San Martín de Jubera & 8 & 3 & 2 & 2 & 1 \\
\hline & 3 & Soto $1-3$ & Soto en Cameros & 24 & 10 & 8 & & 6 \\
\hline & 4 & La Pellejera & Hornillos de Cameros & 69 & 44 & 25 & & \\
\hline & 5 & Hornillos 1-5 & Hornillos de Cameros & 18 & 17 & & & 1 \\
\hline & 6 & Santisol & Hornillos de Cameros & 26 & 25 & 1 & & \\
\hline & 7 & Santa Juliana & Hornillos de Cameros & 2 & 2 & & & \\
\hline & & La Barguilla & Hornillos de Cameros & 3 & 1 & 2 & & \\
\hline & & El Contadero & Ajamil de Cameros & 6 & & 6 & & \\
\hline & 8 & Las Mortajeras & Munilla & 31 & 31 & & & \\
\hline & 9 & Malvaciervo & Munilla & 5 & 2 & 3 & & \\
\hline & 10 & San Vicente de Munilla 1-16 & Munilla & 42 & 42 & & & \\
\hline & & El Sobaquillo & Munilla & 1 & & & 1 & \\
\hline & 11 & Munilla 1-15 & Munilla & 42 & 28 & 14 & & \\
\hline & $*$ & Valdemayor & Cabezón de Cameros & 3 & & 3 & & \\
\hline \multirow[t]{21}{*}{ Enciso-Préjano } & 12 & Barranco de Valdeño & Enciso & 1 & 1 & & & \\
\hline & & Corral de Valdefuentes & Enciso & 2 & & 2 & & \\
\hline & 13 & Las Losas & Enciso & 58 & 58 & & & \\
\hline & 14 & Virgen del Campo 1-4 & Enciso & 56 & 44 & 2 & & 10 \\
\hline & 15 & La Senoba & Enciso & 15 & 12 & & & 3 \\
\hline & 16 & Valdecevillo & Enciso & 27 & 12 & 6 & 3 & 6 \\
\hline & & Valdecevillo Este & Enciso & 3 & 2 & 1 & & \\
\hline & 17 & El Villar-Poyales & Enciso & 15 & 13 & 2 & & \\
\hline & & Icnitas 3 & Enciso & 4 & 4 & & & \\
\hline & 18 & Navalsaz & Enciso & 16 & 1 & 12 & & 3 \\
\hline & 19 & El Corral de Totico 1-2 & Enciso & 21 & 3 & 17 & & 1 \\
\hline & & Barranco de Valdegutierrez 1-2 & Enciso & 5 & 2 & 3 & & \\
\hline & & Cuesta de Andorra & Enciso & 1 & & 1 & & \\
\hline & & La Magdalena & Préjano & 1 & & 1 & & \\
\hline & 20 & Valdeté & Préjano & 1 & & 1 & & \\
\hline & & Tajugueras & Préjano & 2 & & 1 & 1 & \\
\hline & & Perosancio & Muro de Aguas & 1 & & 1 & & \\
\hline & & Perosancio Inferior & Préjano & 1 & 1 & & & \\
\hline & 21 & Valdemurillo & Préjano & 2 & 1 & & 1 & \\
\hline & & Sol de La Pita & Préjano & 1 & 1 & & & \\
\hline & $*$ & La Mata & Peroblasco & 1 & 1 & & & \\
\hline \multirow[t]{11}{*}{ Cornago-Igea } & 22 & Los Cayos A,B,C,D and S & Cornago & 61 & 60 & 1 & & \\
\hline & 23 & Era del Peladillo 1-7 & Igea & 110 & 66 & 22 & 6 & 16 \\
\hline & & Fonsarracín & Igea & 10 & 10 & & & \\
\hline & 24 & La Torre 1-6 and La Torre L & Igea & 228 & 226 & 1 & & 1 \\
\hline & 25 & Las Navas & Igea & 8 & 8 & & & \\
\hline & 26 & Camino Igea a Valdebrajes & Igea & 15 & 11 & 4 & & \\
\hline & 27 & Valdebrajes & Cervera de Río Alhama & 11 & 1 & 10 & & \\
\hline & 28 & Las Navillas & Cervera de Río Alhama & 27 & 20 & & 4 & 3 \\
\hline & $*$ & Valdenocerillo & Cornago & 1 & 1 & & & \\
\hline & & & Total & 992 & 769 & 154 & 18 & 51 \\
\hline & & & $\%$ & & 77.5 & 15.5 & 1.8 & 5.1 \\
\hline
\end{tabular}


avoids artificial duplication and thus provides a more accurate count of individual trackmakers. Since the vast majority of the trackways examined were straight, their orientation was determined using a simple compass. Some trackways showed slight bending, in which case the average direction was determined.

To obtain the true orientation of dinosaur trackways, the data collected may require correction for the tectonic tilt of inclined beds. However, in the present work, most of the trackway-bearing layers examined showed dips of $<25^{\circ}$; the deviation was therefore considered within the range of acceptable error and no adjustment was attempted (Collinson and Thompson, 1989). When working on Iberian trackways, further adjustments may be needed to take into account the anticlockwise rotation of the Iberian Plate. Compared to the present, and based on sea-floor anomalies and palaeomagnetic data, this was rotated by about $40^{\circ}$ in the Aptian and by $35^{\circ}$ in the Berriasian (Sibuet et al., 2004a,b; Gong et al., 2008). However, this was not taken into account in the present work for the sake of simplicity since all the structures examined must have been equally rotated. In any event, future researchers are free to make such corrections as they deem necessary.

A sample of 1170 dinosaur trackways was analysed, 178 from the Huérteles Formation and 992 from the Enciso Group. Most data presented were recorded in situ, although some information was taken from mapped tracksites published in the literature. At each tracksite, the examined trackways were divided into three main categories: ornithopod, theropod and sauropod. For the sake of clarity, the position of all the tracksites examined was plotted on a comprehensive geological map (Fig. 3). The trackway data for the Huérteles Formation came from 18 localities (each of which may contain several tracksites), all in the Province of Soria (Table 1). Of the 178 trackways examined for this formation, 166 were made by theropods, three by ornithopods, eight by sauropods and one remains indeterminate. The Enciso Group trackway data came from three selected areas (Munilla-Hornillos, Enciso-Préjano and Cornago-Igea) with 103 tracksites between them (Table 2). These areas were selected because their tracksites show large numbers of trackways.

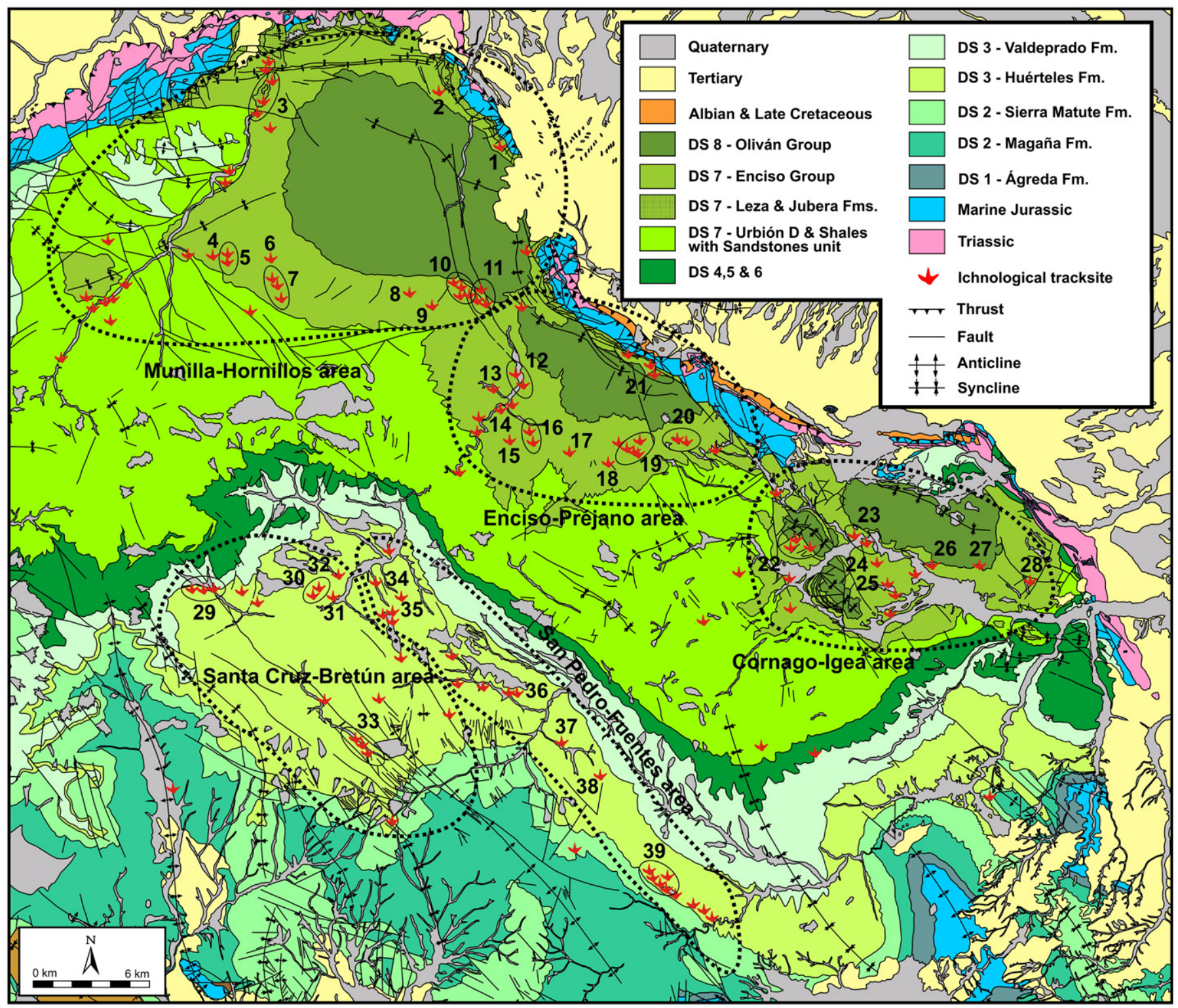

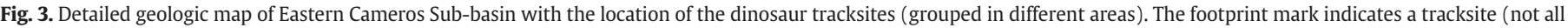

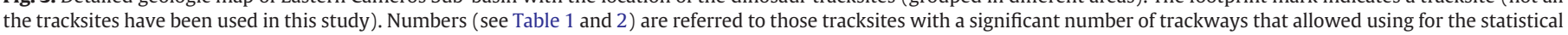
and directional analysis carried out in this paper. 
Some of these sites reveal single layers, but the majority comprise several. Of the 992 Enciso Group trackways examined, 769 had been made by theropods, 154 by ornithopods, 18 by sauropods and 51 by undetermined dinosaurs.

The collected data were analysed using EZ-ROSE software (Baas, 2000). The orientations of the trackways were plotted on circular graphs with a class width of $15^{\circ}$ and a significance level of 0.01 .

\section{Description of the tracksite areas}

\subsection{Huérteles Formation (Berriasian) dinosaur tracksites}

The Huérteles Formation is located at the base of DS-3 (Fig. 2), outcropping along the Provinces of Soria and La Rioja (see also Figs. 1B and 3). Despite the lack of reliable chronological data, the Huérteles Formation is thought to be Berriasian in age (Mas et al., 2002). It represents a new tectonic reorganization and compartmentalization of the Cameros Basin showing only occasional marine influences (Salas et al., 2001; Mas et al., 2003).

Detailed sedimentological and palaeoenvironmental studies of this formation have been undertaken by Gómez-Fernández (1992), Gómez-Fernández and Meléndez (1994a,b), and Meléndez and Gómez-Fernández (2000). Here, a description of the Huérteles Formation is provided in order to better relate the directions of the dinosaur trackways to their depositional environments (based on the above studies). With a maximum sediment thickness of $1050 \mathrm{~m}$, the Formation is characterized by: 1) deposition in a strongly subsiding NW-SE-oriented half-graben with a major border fault at its northeastern margin, plus NE-SW-trending minor intrabasinal faults; 2) a NW-SE-oriented and asymmetrical facies belt; 3) the predominance of terrigenous sediments in the western sector, with carbonates and even evaporites increasing in importance northwards and eastwards until they become dominant; and 4) an increase in salinity eastwards and upwards. The palaeogeographic interpretation of this information suggests the presence of an extensive, tectonicallycontrolled complex record of alluvial plain systems distally connected with playa-lake systems, with an asymmetric arrangement of different sedimentary belts (Fig. 4A). The most proximal palaeoenvironmental complex of the formation, located to the west, is interpreted as a sandy-muddy plain with a predominance of siltstones and sandstones, sometimes showing channel structures. To the east, this palaeoenvironmental complex passes into a mudflat with ephemeralsaline lakes, before finally becoming a carbonate-evaporitic perennialsaline lake complex with mainly limestone sediments plus some evaporitic levels with gypsum pseudomorphs. An alluvial fan/fandelta system developed in response to the footwall uplifting of the border fault, which at this time defined the northeastern margin of the Cameros Basin.

Dinosaur tracksites are abundant in the Huérteles Formation (Sanz et al., 1997; Pérez-Lorente, 2003). However, most have never been described in detail; thus, the available ichnological data is relatively scarce. Some of the cited tracksites (e.g., those mentioned by HernándezMedrano et al., 2005-2006) have names, but no further information is provided for them (sometimes not even their exact position), while others are small and yield just a few individual footprints.

The Huérteles dinosaur tracksites studied come from two main areas (Figs. 3 and 4A). The San Pedro-Fuentes area is home to 6 sites: Miraflores-Umbría del Sastre (39), Valdelavilla (38), El Castillejo (37), San Roque (36), Fuentesalvo (35), and Valdegén (34). The MirafloresUmbría del Sastre tracksites (39) show a multidirectional pattern but slightly biased to a SW orientation. In contrast, Valdelavilla (38) and El Castillejo (37) show rather a bidirectional pattern: NE-SW in the first case and NW-SE in the second. In contrast, Fuentesalvo locality (35) shows a unidirectional NW pattern, relatively similar to that of the San Roque site (36). In contrast, Valdegén clearly shows a multidirectional pattern (34) (Fig. 4B). If we plot together all the dinosaur trackways from the San Pedro-Fuentes area we obtain a multidirectional rose diagram but slightly biased to the NW (Fig. 4A) suggesting a dinosaur preferential movement relatively parallel to the inferred water body.

The Santa Cruz-Bretún area contains 5 dinosaur localities: Serrantes (32), Santa Cristina (31), Bretún tracksites (30), Santa Cruz de Yanguas (29), and Los Campos (33) (Fig. 4A). Some of these tracksites show a multidirectional pattern, especially evident in the different localities of Santa Cruz de Yanguas (29). Other localities show a clear bidirectional pattern like Bretún (30) but most show an almost unidirectional model like Santa Cristina (31), Los Campos (33) or even Serrantes (32) (Fig. 4B). The whole sample of the Santa CruzBretún area shows a multidirectional model slightly biased to the NNE direction (Fig. 4A).

\subsection{Enciso Group (Lower Aptian) dinosaur tracksites}

The Enciso Group is the uppermost unit of DS-7 (Fig. 2), outcropping only in the Province of La Rioja. Its overall structure is defined by an extensive synclinorium with great development of its longitudinal axial trace (about $70 \mathrm{~km}$ long) that shows a preferential NW-SE orientation (parallel to the trace of the thrust) (Fig. 3). The southern flank comprises a thick (up to $1400 \mathrm{~m}$ ) gently dipping sequence while the northern flank shows steeper dip angles, is thinner (up to $300 \mathrm{~m}$ ), and shows more complexity and tectonic fracturing. An early Aptian age can be inferred from the evidence of charophytes, dasyclad algae and regional geology (Alonso and Mas, 1993; Martín-Closas and Alonso-Millán, 1998; Doublet and Garcia, 2004).

The Enciso Group, in the depocentral area of the basin (the Enciso stratigraphic section), encompasses a sequence formed by two units. The lower, siliciclastic-rich unit, which is up to $600 \mathrm{~m}$ thick, shows an alternation of mudstones, sandstones, and minor marlstones and limestones. The upper unit, which is up to $800 \mathrm{~m}$ thick, is arranged into large-scale (metric to decametric) cyclical carbonate- and siliciclasticdominated sedimentary packages. This pattern is similar to other stratigraphic sections examined in track-rich areas several kilometres away (Doublet et al., 2003; Moratalla et al., 2003; Doublet and Garcia, 2004). The great majority of tracksites occur in this upper unit either in siliciclastic and carbonate-rich packages. These carbonate-dominated packages are laterally extensive and consist of locally bioturbated, meter-scale interbedded grey-dark marlstones and limestones (massive or sparsely laminated micrite with mudstone and/or wackestone textures). Their profuse mottling, nodular appearance and desiccation cracks suggest frequent subaerial-exposure, although the lack of welldeveloped paleosoils implies exposure times were short. These packages represent deposition in low-energy ramp-type carbonatelacustrine systems (sensu Platt and Wright, 1991) with development of palustrine environments in an extensive lake-margin area with shallow water as is common in these types of lakes (Alonso-Zarza, 2003). Such a palaeoenvironment would probably have favoured the formation/preservation of vertebrate tracks. The siliciclastic-dominated packages also show an extensive lateral continuity and a common coarsening-upward trend, comprising tabular bodies of lutites with minor intercalated sandstones beds. They are interpreted to represent a complex mosaic of fluvio-deltaic environments related to avulsion belts similar to modern and ancient examples described by many authors (e.g., Kraus and Wells, 1999; Makaske, 2001; Slingerland and Smith, 2004).

The Enciso Group has yielded more dinosaur tracksites than any of the other groups mentioned. Most were examined in the present analysis (Table 2), and their orientations generally found to show a general bidirectional pattern, with each site showing variations in direction. At some the directional range of the trackways was relatively narrow, while at others it was much wider. In addition, at some tracksites the two main directions of movement were represented by similar numbers of trackways, while at others one 
A
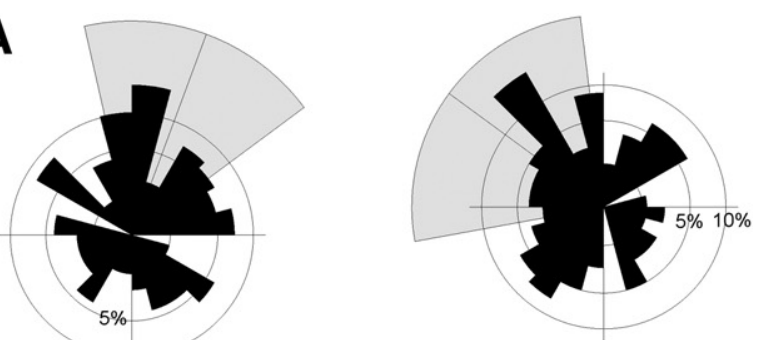

4

r

$\uparrow$

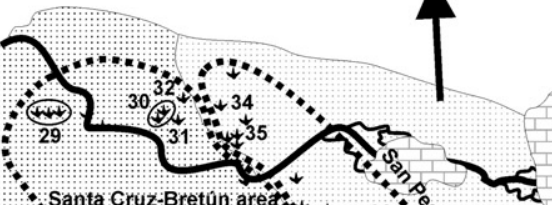

$\because: 3$

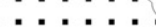

......

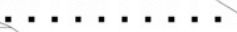

$\ldots \ldots$

$2,2: 2: 2$
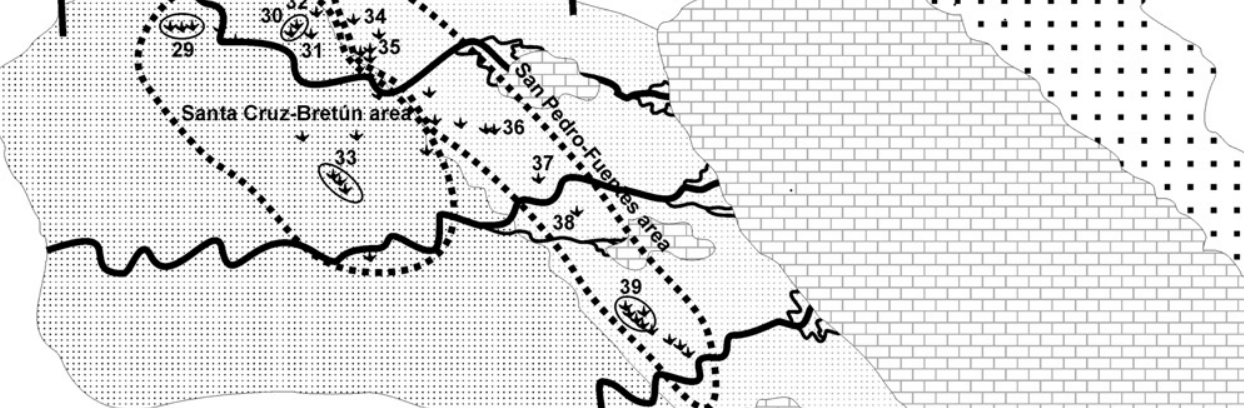

$\because:-$

$\cdots \cdots$

$\therefore:-1$

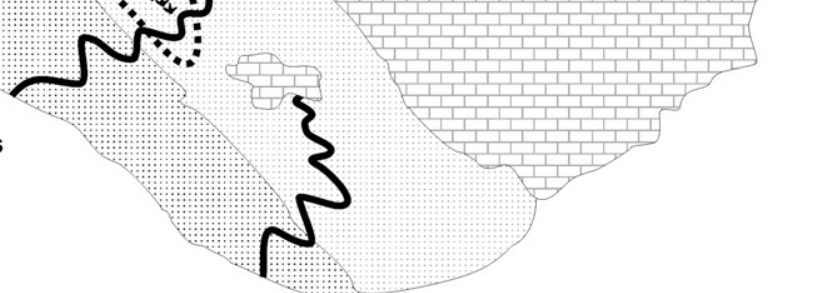

Perennial-saline lake

-. Alluvial fan / Fan-delta

B
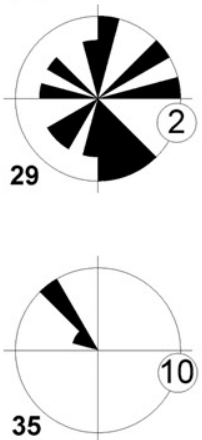

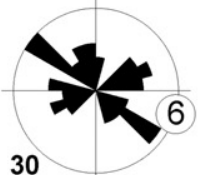

30

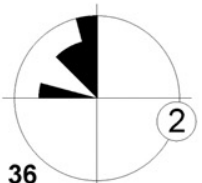

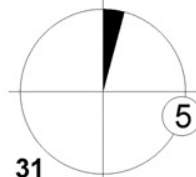

31

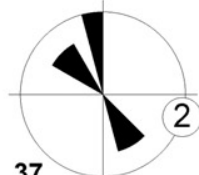

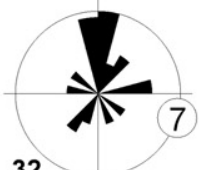

32

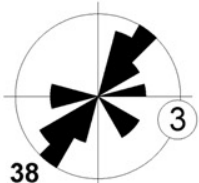

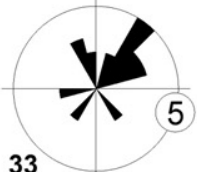

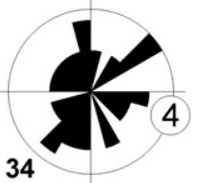

34

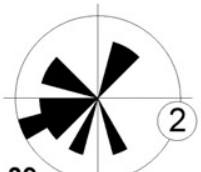

39

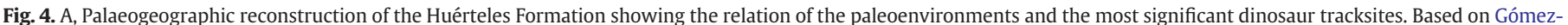

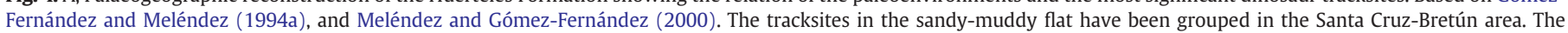

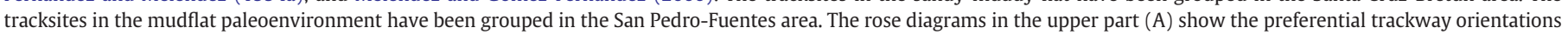

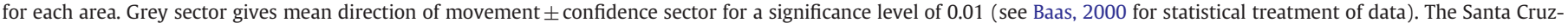

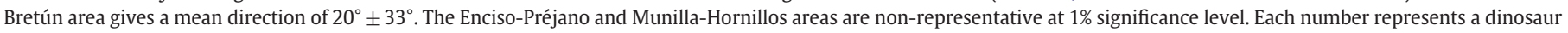

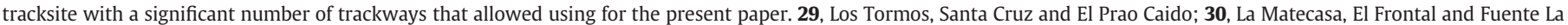

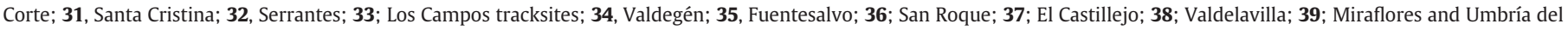

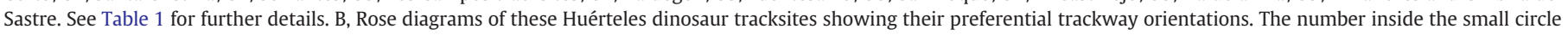
indicates the number of trackways for the highest frequency sector.

particular direction was dominant (see Fig. 5 for further details). Three main areas can be outlined for the Enciso Group dinosaur tracksites: Munilla-Hornillos, Enciso-Préjano and Cornago-Igea (Figs. 3 and 5A) that have yielded a slightly different general trackway orientation. So, the Munilla-Hornillos region (located to the NW of the map) shows a general NE-SW bidirectional pattern. By contrast, the Enciso-Préjano area does not show a clear bidirectional distribution but rather a multidirectional one with a slight preference in a NNW-SSE pattern. On the contrary, the Cornago-Igea area clearly shows a bidirectional NNW-SSE pattern, especially evident in La Torre (24), Era del Peladillo (23) or La Senoba (15) localities. However, some local variations could be pointed out like that of the Los Cayos locality (22), showing a clear E-W bidirectional pattern or El VillarPoyales (17), with a NW-SE distribution (Fig. 5B).

\section{Discussion}

Two prerequisites are necessary for the present type of trackway direction analysis: 1) a large number of trackways comprising a representative sample, and 2) approximately synchronic time intervals for the different trackways examined. The present work examined 1170 trackways, unlike the smaller number examined in earlier works 

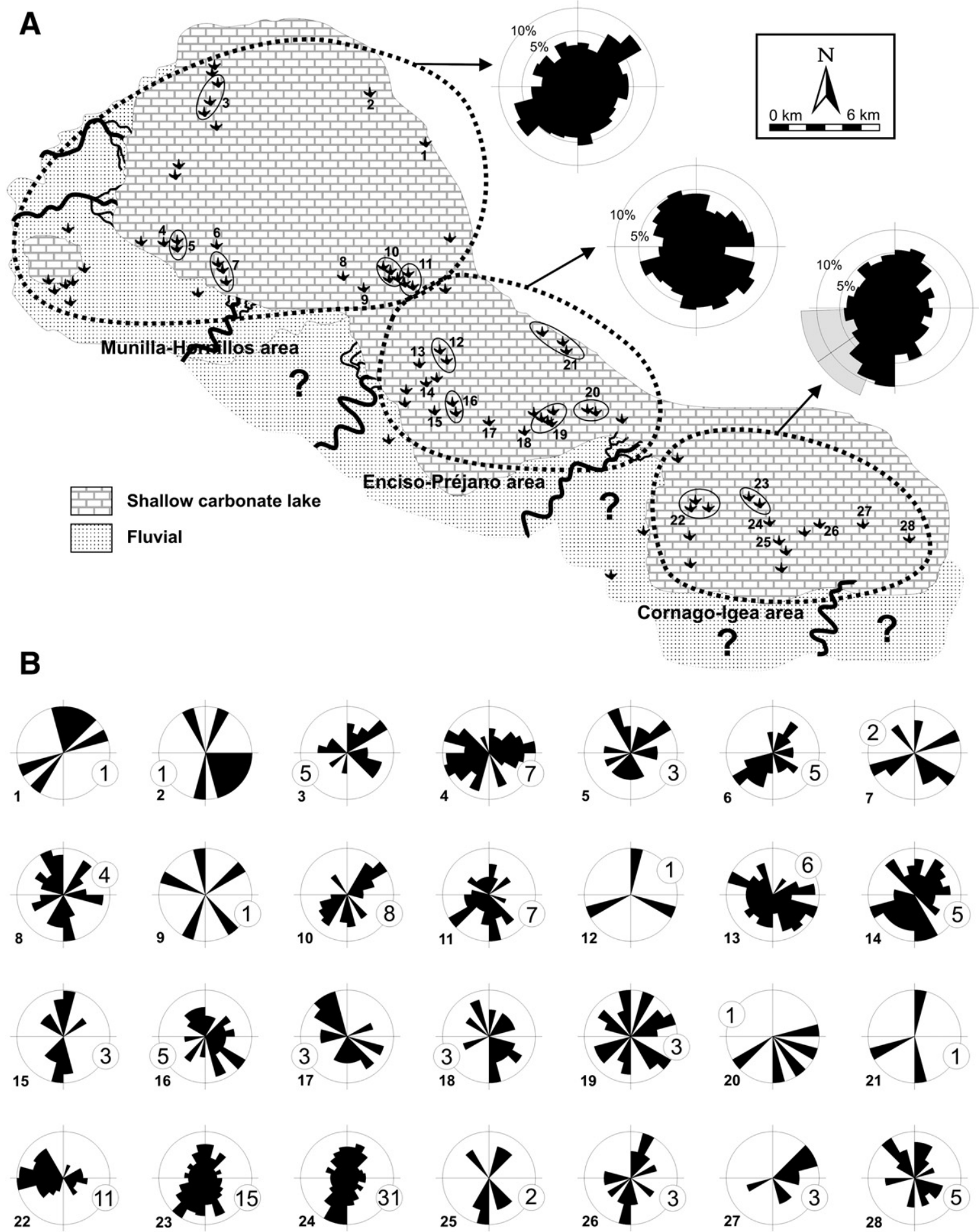

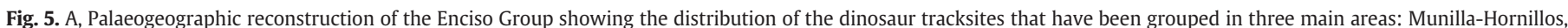

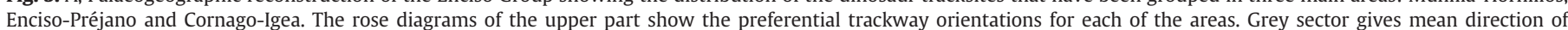

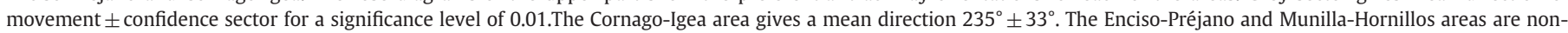

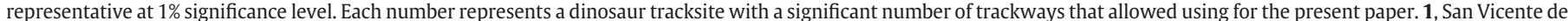

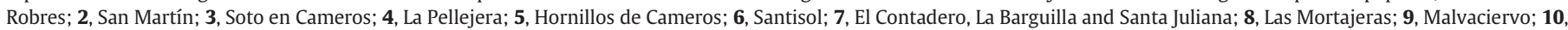

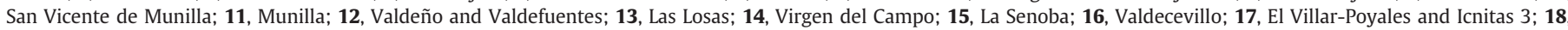

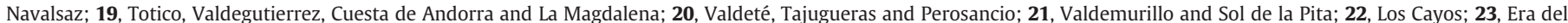

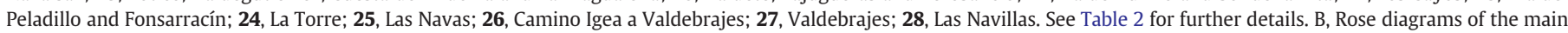

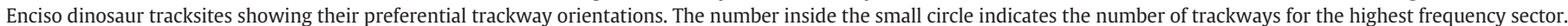

involving the Jindong (Lockley and Matsukawa, 1998; Paik et al., 2001; Lockley et al., 2006a), Sousa (Leonardi, 1994; Leonardi and Dos Santos, 2004) or El Molino Formations (Meyer et al., 2001). Further, the tracksites analysed in the present work are all thought to have been made in the Berriasian or Aptian. Nonetheless, their exact stratigraphic correlation remains somewhat uncertain because of the great tectonic complexity of the basin, the location of dinosaur tracksites in different areas, the high rate of lateral facies change, and the relative abundance 
of faults, etc. Consequently, the tracksites examined in this analysis may not be entirely synchronous, although they are located throughout the stratigraphic sections of both the Huérteles Formation and the Enciso Group. Further, some tracksites hundreds or even thousands of meters apart belong to the same siliciclastic (Munilla-San Vicente de Munilla or Los Cayos A-B-C) or carbonate packages (ValdetéTajugueras-Perosancio). Finally, the Enciso Group may represent a period of about 4-5 Ma (according to the geological time scale of Gradstein et al. (2005)), but might in fact only cover some 1-2 Ma if the timescale proposed by Fiet et al. (2006) is followed. Moreover, the stratigraphic distribution of the tracksites is not uniform; the majority of the track-bearing sequences appear in the upper two-thirds of the Enciso Group section, reducing the estimated time interval to which they might belong. Finally, the cyclicity of the Enciso sedimentary succession suggests that the same general palaeogeographic and palaeoenvironmental conditions probably reigned over the entire Enciso Group deposition episode.

\subsection{Huérteles Formation}

The most common trackway movement pattern for the ichnocenoses of the Huérteles Formation seems to be multidirectional (Fig. 4). Sometimes, however, it is almost bidirectional or unidirectional, and sometimes two directions cross one another. Fig. 6 shows the directional plot for 178 dinosaur trackways. Compared to the trackways of the Enciso group, these show a relatively wide range of directions, although

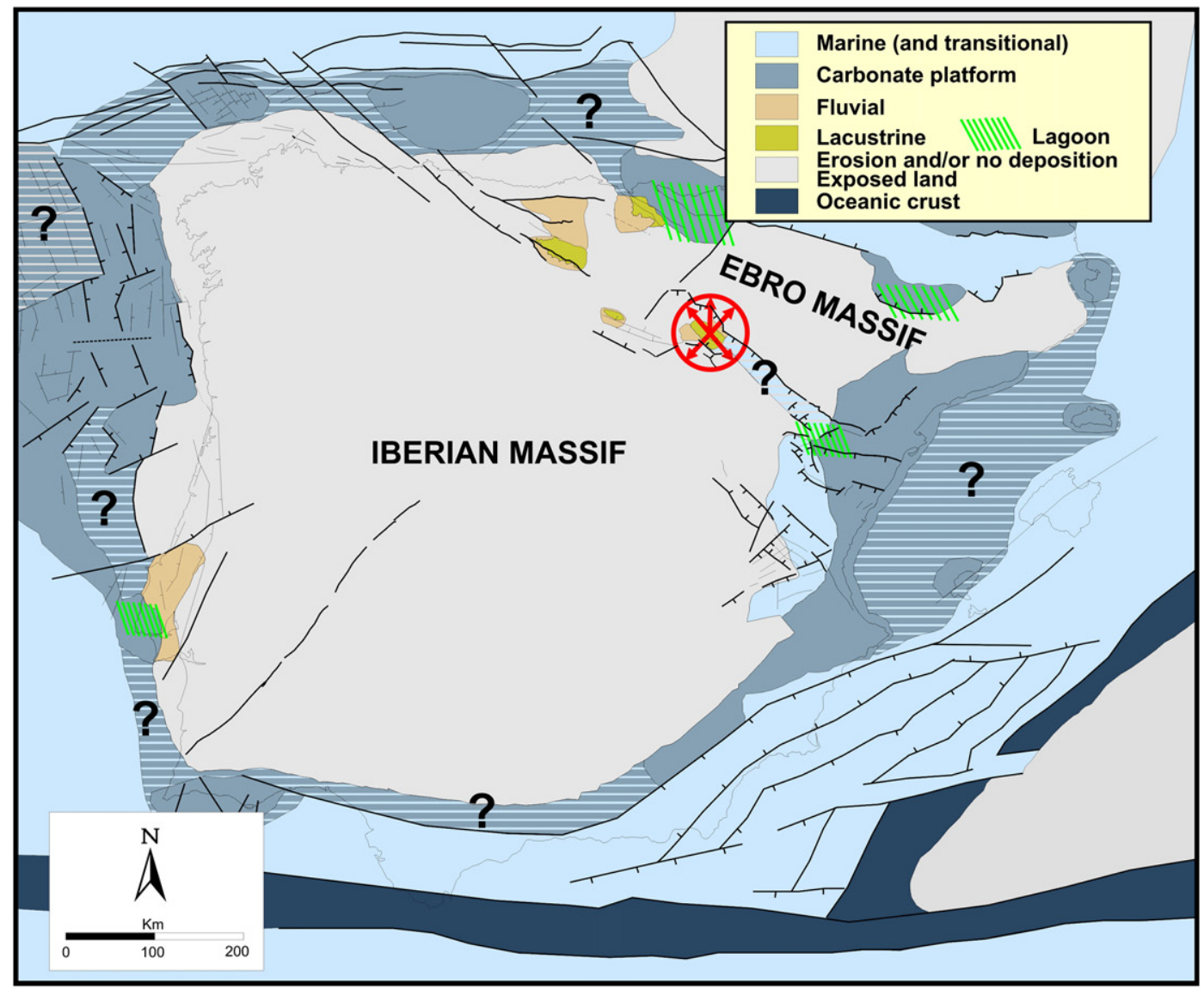

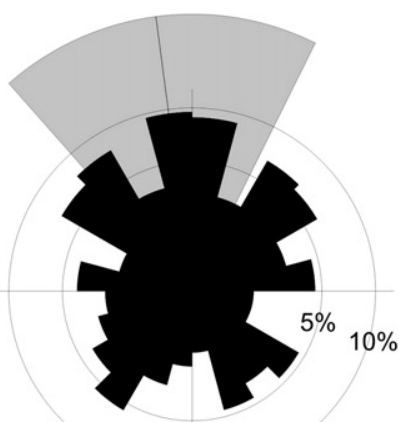

Total trackways $(n=178)$

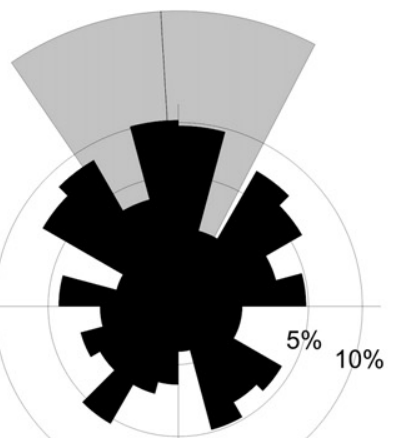

Theropod trackways $(n=166)$

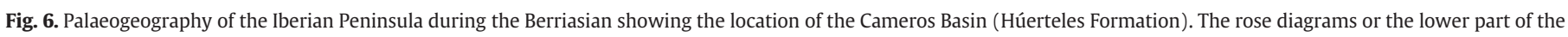

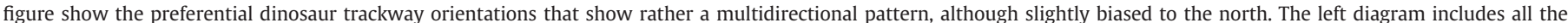

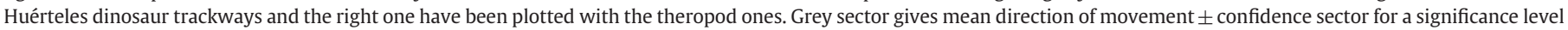

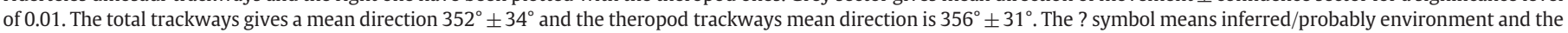
two-color striped area indicates a mixture of the two environments (lack of reliable data) indicated by the colors. 
there is a slight preference to the North. In addition, Fig. 4 strongly suggests that the spatial distribution of the tracksites themselves obeys a phenomenon of palaeoenvironmental distribution. This spatial preference for tracksites may be the result of preservation factors and/or the animals' palaeohabitat preferences. The first hypothesis explains the absence of tracks in the northeastern alluvial fan/fan-delta system. Nevertheless, the lack of any footprint on the margins of the perennialsaline lake complex (Fig. 4A) or in the eastern sector of the mudflat environment (Fig. 4A), seems not to be due to preservation factors alone since relatively similar ancient playa-lake systems, such as those of the Jindong (Paik and Kim, 2006 versus Houck and Lockley, 2006) or East Berlin Formations (Gierlowski-Kordesch and Rust, 1994) show abun- dant trackways. Consequently, it is here assumed that the absence of dinosaur tracks in these areas is due to reasons of preferred habitat; a lack of freshwater may have been a key factor. If this is so, two main conclusions can be drawn: 1 ) that dinosaur tracksites are mainly located throughout the more proximal facies of the basin, quite far from the central saline lacustrine complex; and 2) that the general directional pattern suggests that animals walked relatively parallel to the sedimentary facies belts. This conclusion would be consistent with a predominance of animal movements parallel to the water body.

This fact suggests that the preferential dinosaur movements during Huérteles Formation deposition were probably more influenced by the local paleoenvironmental conditions than by from the
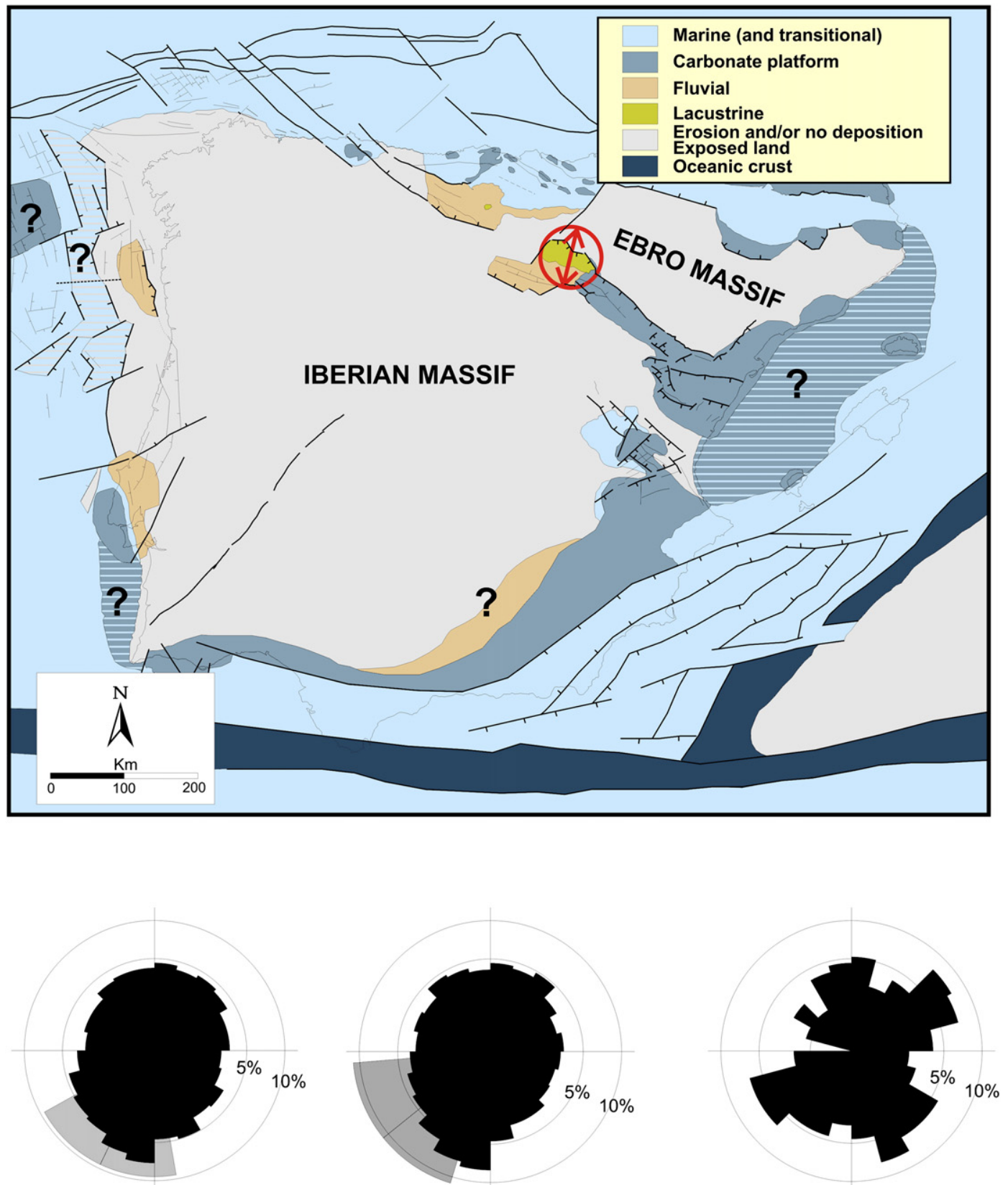

\section{Total trackways $(n=992)$ Theropod trackways $(n=769)$ Ornithopod trackways $(n=154)$}

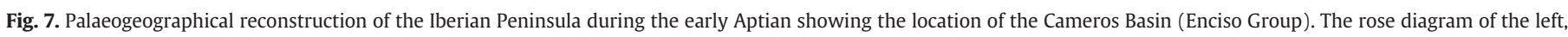

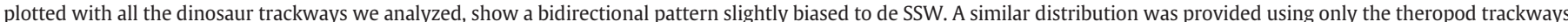

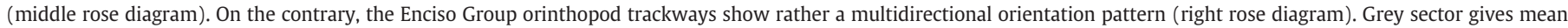

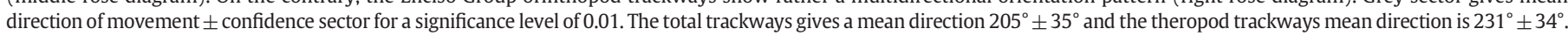
The ? symbol means inferred/probably environment and the two-color striped area indicates a mixture of the two environments (lack of reliable data) indicated by the colors. 
general paleogeographic land distribution shown in Fig. 6. This conclusion seems to be different that those inferred from the Enciso Group paleogeographic analysis, as we will see in the next section.

\subsection{Enciso Group}

The trackway pattern for the Enciso Group is quite different, with a clear bidirectional pattern distribution for the Munilla-Hornillos and Cornago-Igea areas and a more multidirectional distribution for the Enciso-Préjano one. A coherent explanation for these differences is difficult to propose. The simplest answer may be related to differences in the spatial and temporal palaeoenvironmental characteristics of these areas. In fact, although most of these dinosaur tracksites are located in the upper part of the Enciso Group, their exact chronostratigraphic correlations are not completely understood. Further work will be necessary if a detailed correlation among tracksites is to be obtained.

Fig. 7 is a plot of the results for the entire Enciso Group sample $(n=992)$. The graph suggests that the preferential trackway orientation is NNE-SSW, although this preferential orientation seems to be more evident for theropods than for ornithopods. These results are probably the consequence of the general paleogeographic conditions of the Cameros Basin during the deposition of the Enciso Group. So, a positive correlation appears to exist between the eustatic rise in sea level and the deposition of the Enciso Group (Mas et al., 1993). Thus, compared to the Berriasian of the Huérteles Formation, the palaeogeographic setting of the Iberian Plate changed significantly in the earliest Aptian. The significant global rise in sea level combined with the extensional regime of Iberia facilitated a marine transgression with Boreal affinities (Wilmsen, 2005) from the north (BasqueCantabrian Basin), as well as that of the Tethys Sea from the southeast (MIRS) (Salas et al., 2001; Mas et al., 2002). This led to the partition of the Iberian Plate into two major emerged areas - the Ebro Massif (northeast) and the Iberian Massif (southwest) (Fig. 7) - largely separated by the sea, the only land communication between them being the Cameros Basin. Therefore, during the Lower Aptian, the Cameros Basin was the only route that dinosaurs (and, of course, other terrestrial animals) could take between these massifs (Moratalla and Hernán, 2007; 2008). The finding of dasycladaceas throughout the Leza Formation (part of the Enciso Group) suggests several short-lived invasions of Tethys marine water masses into the Cameros Basin, with a stable NW land limit near the Moncayo Mountain (Malacara Formation) (Alonso and Mas, 1988). The width of the corridor between the northern marine limit and the southern marine limit can be estimated at $100 \mathrm{~km}$ following a NNW-SSE transect.

The preferential orientations of the Enciso Group dinosaur trackways would be consistent with these described paleoenvironmental conditions (see Fig. 5A and Fig. 7). Their general orientation suggests that dinosaurs, especially the theropods, travelled through this large Enciso lacustrine complex following preferred regional routes. So, they passed through the lake basin in a preferential NNE-SSW direction (as we can observe in Fig. 5A) strongly influenced by the paleogeographical conditions reflected in Fig. 7. This hypothesis would be clearly in contrast with the orientation pattern observed in the Huérteles Formation localities (Fig. 4A), and also in other wellknown lacustrine areas from which a preferential dinosaur movement parallel to the coast/shore has been deduced (Lockley and Price, 1988; Lockley, 1991; Lockley et al., 1992; Meyer et al., 2001).

As discussed above, whatever the rift-basin structure contemplated, both the sedimentological evidence and stratal architecture suggest the presence of an Enciso palaeolake complex with a sagbasin morphology rather than the classic half-graben model. A saglike lacustrine complex would suggest the presence of a greatly fluctuating level of lake water in a shallow environment. Sag-type lakes are characterized by a very large surface area covered by shallow water (they therefore have large littoral areas), and gentle bottom slopes; the shorelines of such lakes would therefore be very sensitive to fluctuations in the water level. These conditions imply shoreline shifts and the exposure of wide areas of mud, which dinosaurs might trample. An outstanding example was cited by Mohler et al. (1995) in Lake Chad; these authors reported that a fall in the lake's water level of $3 \mathrm{~m}$ caused a lakeward migration of the shoreline of some $18 \mathrm{~km}$. A sag-like lacustrine complex would also suggest the absence of high relief produced by footwall uplift. Present-day rift-escarpment margins can be very high due to footwall uplift, perhaps exceeding thousands of meters in height (Cohen, 1990; Le Turdu et al., 1999; McGlue et al., 2006); such a landscape would represent an insurmountable obstacle to dinosaur movement. If the above inferences are correct, then the area of the shallow lacustrine complex would have been the only option for animal movement through the Enciso palaeoenvironmental system. It is possible that some local progradational avulsion (many tracksites occur at the top of avulsion deposits) and/or low lake-level episodes (many track-bearing layers show mud-cracked bedding planes) gave rise to contractions of the water body creating emergent passages facilitating such movement. Relatively prolonged dry episodes, such as that shown by the drying of modern Lake Victoria (Johnson et al., 1996; Stager and Johnson, 2008) or Lake Tana (Lamb et al., 2007), may have facilitated animal
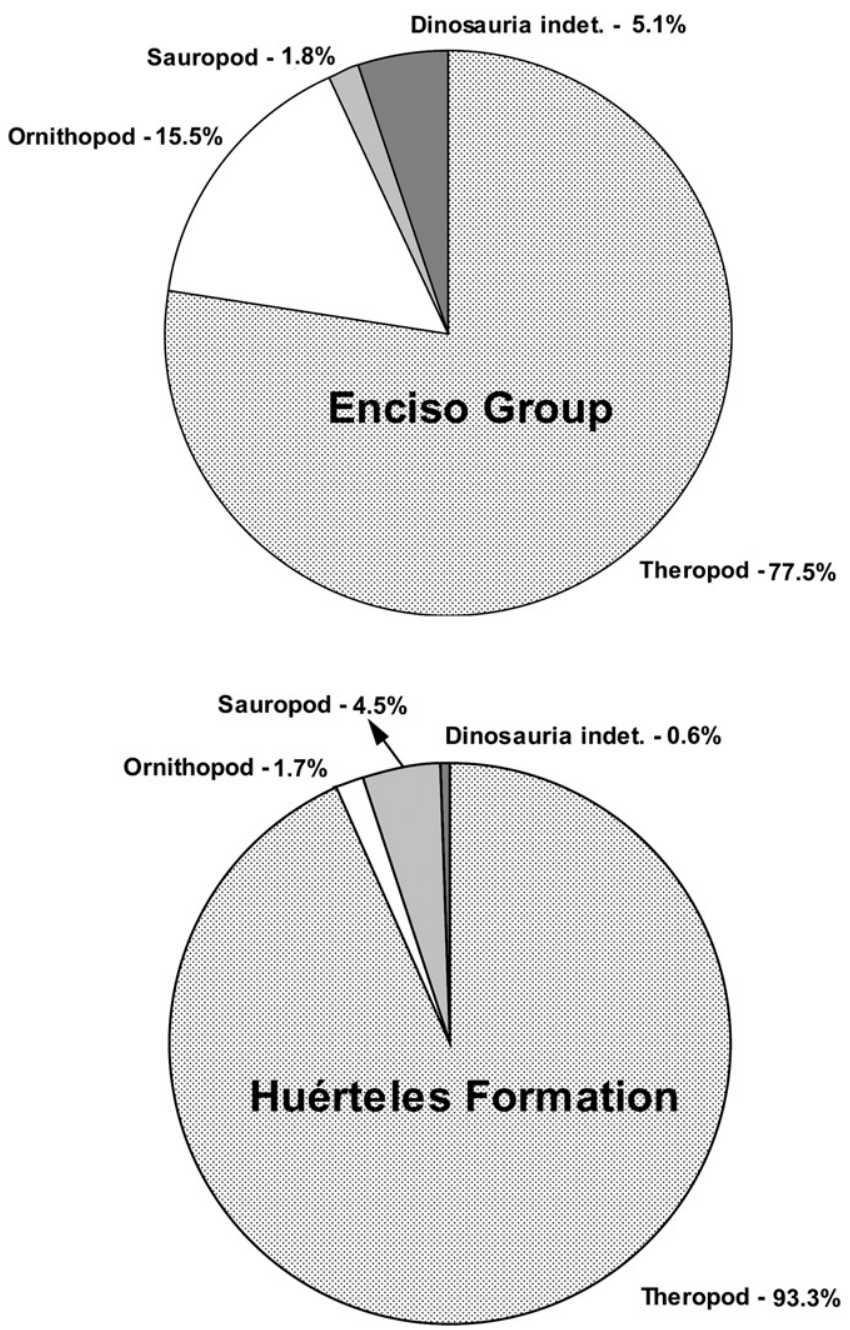

Fig. 8. Both Huérteles and Enciso ichnocenoses - based on trackways - show a clear domination of theropod dinosaurs that seem to be more abundant during the Berriasian and experienced a descent of about $16 \%$ for the Aptian. On the contrary, ornithopod dinosaurs bear a significant increment from the Berriasian (1.7\%) up to the Aptian (15.5\%), while sauropod dinosaurs seem to be the less abundant trackway makers during both periods. 
movement. Nevertheless, no complete desiccation of the Cameros palaeolake seems to have occurred; no evidence of a well-developed palaeosoil has yet been found.

This lacustrine-complex scenario is consistent with the directional pattern of the dinosaur tracks for the Enciso Group, but it does not explain the existence of an ichnocenosis clearly dominated by predatory dinosaurs. The same is true of the Huérteles Formation. Clearly, both events are relatively similar in that they are dominated by theropod trackways (93.3\% for the Huérteles Formation and 77.5\% for the Enciso Group) (Fig. 8) (Moratalla, 2008). However, ornithopod tracks are far less abundant in the Huérteles Formation (1.7\% compared to $15.5 \%$ for the Enciso Group), while sauropod tracks are more abundant (4.5\% compared to $1.8 \%$ for the Enciso Group). Avian-like and pterosaur tracks are more abundant in the Huérteles Formation than in the Enciso Group (Moratalla, 2008). Almost certainly the apparently high percentages of predatory theropods reflect their activity rather than the true composition of the palaeocommunity. These dinosaurs were significantly more active than others, a consequence of their searching/ hunting behaviour. Herbivorous dinosaurs such as ornithopods and sauropods probably inhabited wider areas, over which their food sources would be more plentiful, but where the conditions for track preservation would be at their worst. Shallow-water dwellers and/or active animals such as the theropods would have found a home more to their liking in the central lacustrine basin; these then moved along a NESW axis as part of their hunting lifestyle.

\section{Conclusions}

- Two different preferential orientation dinosaur trackway patterns can be deduced from the Berriasian and from the Aptian of the Cameros Basin. These differences seem to be related to the different paleogeographical conditions in both stages.

- The location and preferred orientation of the Huérteles Formation dinosaur trackways seem to be related to the facies belts. So, they show a rather multidirectional preferential orientation pattern but slightly biased to the north, suggesting a preferential dinosaur movement parallel to the water body.

- The Huérteles Formation orientation pattern seems to be heavily conditioned by the presence of a perennial-saline lake complex from which no dinosaur tracksites have been found.

- During the Aptian (reflected by the Enciso Group), a double transgression from the north and from the southeast occurred, resulting in the partition of the Iberian Plate into two main emergent areas connected by the Cameros pathway.

- The Enciso Group landscape was formed by a broad shallow lacustrine system that experienced fluctuations in its water level. Large areas of exposed sediment were trampled by dinosaurs as they followed their preferred regional route of movement. So, these dinosaurs passed through the lake mainly in a preferential NE-SW orientation heavily conditioned the geographical distribution of the land masses.

- The ichnocenosis of the Cameros Basin - based on trackways shows that theropod dinosaurs were the most abundant trackway makers ( $85.3 \%$ as a mean value). The percentage of ornithopod trackways is significantly larger in the Enciso Group (15.5\%) than in the Huérteles Formation (1.7\%), while the percentage of sauropod trackways is more abundant similar in the Huérteles Formation (4.5\%) to the Enciso Group (1.8\%). The theropod trackways are the most abundant in both periods (93.3\% in Huérteles Formation and 77.5\% in the Enciso Group).

- The almost absolute dominance of theropods in the Cameros Basin ichnocenoses suggests that these dinosaurs were significantly more active than others, a likely reflection of the searching/hunting behaviour typical of such predatory groups.

\section{Acknowledgements}

We wish to thank Mr. Santiago Jiménez, director of the Museo de Ciencias Naturales of Arnedo (La Rioja) for his help in the field work and also to many volunteers from several amateur associations from Préjano, Cornago and Arnedo towns (La Rioja province). Thanks to the editor and reviewers (Dr. Jesper Milàn and an anonymous one) for their helpful and valuable comments for improvements. We are also grateful to Dr. Ramón Mas and Dr. Isabel Benito for their reviews of the original manuscript. This paper was supported by the project CGL2006-10380 of the Spanish Ministry of Science for the study of Lower Cretaceous biodiversity and the project CGL2008-01648/BTE. Adrian Burton revised the English version.

\section{References}

Alonso, A., Mas, J.R., 1988. La transgresión aptiense al sur del Moncayo (límite de las provincias de Soria y Zaragoza). II Congreso Geológico de España, Granada, pp. 11-14.

Alonso, A., Mas, J.R., 1993. Control tectónico e influencia del eustatismo en la sedimentación del Cretácico inferior de la cuenca de Los Cameros. Cuadernos de Geología Ibérica 17, 285-310.

Alonso-Zarza, A.M., 2003. Palaeoenvironmental significance of palustrine carbonates and calcretes in the geological record. Earth Science Reviews 60 (3-4), 261-298.

Arribas, J., Alonso, A., Mas, R., Tortosa, A., Rodas, M., Barrenechea, J.F., Alonso-Azcarate, J., y Artigas, R., 2003. Sandstone petrography of continental depositional sequences of an Intraplate Rift Basin: Western Cameros Basin (North Spain). Journal of Sedimentary Research 73 (2), 309-327.

Baas, J.H., 2000. EZ-ROSE: a computer program for equal-area circular histograms and statistical analysis of two-dimensional vectorial data. Computers \& Geosciences 26 (2), 153-166.

Bird, R.T., 1944. Did Brontosaurus ever walk on land? Natural History 53, 60-67.

Casanovas, M.L., Santafé, J.V., 1971. Icnitas de reptiles mesozoicos en la provincia de Logroño. Acta Geologica Hispánica 6 (5), 139-142.

Cohen, A.S., 1990. Tectono-stratigraphic model for sedimentation in Lake Tanganyika, Africa. In: Katz, B.J. (Ed.), Lacustrine Basin Exploration-Case Studies and Modern Analogs: AAPG Memoir, vol. 50, pp. 137-150.

Collinson, J.D., Thompson, D.B., 1989. Sedimentary Structures. Routledge.

Currie, P.J., Sarjeant, W.A.S., 1979. Lower Cretaceous dinosaur footprints from the Peace River Canyon, British Columbia, Canada. Palaeogeography, Palaeoclimatology, Palaeoecology 28, 103-115.

Doublet, S., Garcia, J.P., 2004. The significance of dropstones in a tropical lacustrine setting, eastern Cameros Basin (Late Jurassic-Early Cretaceous, Spain). Sedimentary Geology 163 (3-4), 293-309.

Doublet, S., García, J.P., Guiraud, M., Ménard, A., 2003. Wave-dominated siliciclastic and carbonate sedimentation in a Lower Cretaceous lake (Cameros Basin, northern Spain). Journal of Iberian Geology 29, 11-28.

Farlow, J.O., Langston Jr., W., Deschner, E.E., Solis, R., Ward, W., Kirkland, B.L., Hovorka, S., Reece, T.L., Whitcraft, J., 2006. Texas Giants: Dinosaurs of the Heritage Museum of the Texas Hill County. Heritage Museum of the Texas Hill County, Texas.

Fiet, N., Quidelleur, X., Parize, O., Bulot, L.G., Gillot, P.Y., 2006. Lower Cretaceous stage durations combining radiometric data and orbital chronology: towards a more stable relative time scale? Earth and Planetary Science Letters 246 (3-4), 407-417.

García-Mondéjar, J., Aguirrezabala, L.M., Aranburu, A., Fernádez-Mendiola, P.A., GómezPérez, I., López-Horgue, M., Rosales, I., 1996. Aptian-Albian tectonic pattern of the Basque-Cantabrian Basin (northern Spain). Geological Journal 31 (1), 13-45.

Gaston, R., Lockley, M.G., Lucas, S.G., Hunt, A.P., 2003. Grallator-dominated fossil footprint assemblages and associated enigmatic footprints from the Chinle Group (Upper Triassic), Gateway Area, Colorado. Ichnos 10 (2-4), 153-163.

Getty, P.R., 2005. Excavated and in situ dinosaur footprints from the Murray Quarry (Early Jurassic East Berlin Formation), Holyoke, Massachusetts, USA. Ichnos 12 (3) 163-178.

Gierlowski-Kordesch, E., Rust, B.R., 1994. The Jurassic East Berlin Formation, Hartford Basin, Newark Supergroup (Connecticut and Massachusetts): a saline lake-playaalluvial plain system. In: Renaut, R.W., Last, W.M. (Eds.), Sedimentology and Geochemistry of Modern and Ancient Saline Lakes: SEPM Special Publication, vol. 50, pp. 249-265.

Gillette, D.D., Thomas, D.A., 1985. Dinosaur tracks in the Dakota Formation (AptianAlbian) at Clayton Lake State Park, Union County, New Mexico. New Mexico Geological Society Guidebook, 36th Field Conference, Santa Rosa, pp. 283-288.

Gómez-Fernández, J.C., 1992. Análisis de la Cuenca sedimentaria de los Cameros durante sus etapas iniciales de relleno en relación con su evolución paleogeográfica, $\mathrm{Ph}$. D. Thesis. Universidad Complutense de Madrid, Madrid, 343 pp.

Gómez-Fernández, J.C., Meléndez, N., 1994a. Climatic control on Lower Cretaceous sedimentation in a playa-lake system of a tectonically active basin (Huérteles Alloformation, Eastern Cameros Basin, North-Central Spain). Journal of Paleolimnology 11 (1), 91-107.

Gómez-Fernández, J.C., Meléndez, N., 1994b. Estratigrafía de la "Cuenca de los Cameros" (Cordillera Ibérica Noroccidental, N de España) durante el tránsito JurásicoCretácico. Revista de la Sociedad Geológica de España 7 (1-2), 121-139. 
Gong, Z., Langereis, C.G., Mullender, T.A.T., 2008. The rotation of Iberia during the Aptian and the opening of the Bay of Biscay. Earth and Planetary Science Letters 273 (1-2), 80-93.

Gradstein, F.M., Ogg, J.G., Smith, A.G., 2005. A Geologic Time Scale 2004. Cambridge University Press, Cambridge.

Guimerà, J., Alonso, Á., Mas, J.R., 1995. Inversion of an extensional-ramp basin by a newly formed thrust: the Cameros basin (N. Spain). In: Buchanan, J.G., Buchanan, P.G. (Eds.), Basin Inversion. Geological Society, London, pp. 433-453.

Hernández-Medrano, N. Pascual-Arribas, C., Latorre-Macarrón, P., Sanz-Pérez E. 2005 2006. Contribución de los yacimientos de icnitas sorianos al registro general de Cameros. Zubia 23/24, 79-120.

Houck, K.J., Lockley, M.G., 2006. Life in an active volcanic arc: petrology and sedimentology of dinosaur track beds in the Jindong Formation (Cretaceous), Gyeongsang Basin, South Korea. Cretaceous Research 27 (1), 102-122.

Huh, M., Hwang, K.G., Paik, I.S., Chung, C.H., Kim, B.S., 2003. Dinosaur tracks from the Cretaceous of South Korea: distribution, occurrences and paleobiological significance. Island Arc 12 (2), 132-144.

Jenkins, F.A., Shubin, N.H., Amaral, W.W., Gatesy, S.M., Schaff, C.R., Clemmensen, L.B. Downs, W.R., Davidson, A.R., Bonde, N., Osbaeck, F., 1994. Late Triassic continental vertebrates and depositional environments of the Fleming Fjord Formation, Jameson Land, East Greenland. Meddelelser om Gronland. Geoscience 32, 1-25.

Johnson, T.C., Scholz, C.A., Talbot, M.R., Kelts, K., Ricketts, R.D., Gideon, N., Beuning, K. Ssemmanda, I., McGill, J.W., 1996. Late Pleistocene desiccation of Lake Victoria and rapid evolution of Cichlid Fishes. Science 273 (5278), 1091-1093.

Kraus, M.J., Wells, T.M., 1999. Recognizing avulsion deposits in the ancient stratigraphical record. In: Smith, N.D., Rogers, J. (Eds.), Fluvial Sedimentology VI. Special Publication of the International Association of Sedimentologists, pp. 251-268.

Lamb, H.F., Bates, C.R., Coombes, P.V., Marshall, M.H., Umer, M., Davies, S.J., Dejen, E., 2007. Late Pleistocene desiccation of Lake Tana, source of the Blue Nile. Quaternary Science Reviews 26 (3-4), 287-299.

Lambiase, J.J., 1990. A model for tectonic control of lacustrine stratigraphic sequences in continental rift basins. In: Katz, B.J. (Ed.), Lacustrine Basin Exploration-Case Studies and Modern Analogs: AAPG Memoir, vol. 50, pp. 265-276.

Langston, W., 1979. Lower Cretaceous dinosaur tracks near Glen Rose, Texas. In: Perkins, B.F., Langston Jr., W. (Eds.), Lower Cretaceous Shallow Marine Environments in the Glen Rose Formation: Dinosaur Tracks and Plants-Field Trip Guide. American Association of Stratigraphic Palynologists Annual Meeting, pp. 39-61.

Le Turdu, C., Tiercelin, J.-J., Gibert, E., Travi, Y., Lezzar, K.-E., Richert, J.-P., Massault, M., Gasse, F., Bonnefille, R., Decobert, M., Gensous, B., Jeudy, V., Tamrat, E., Mohammed, M.U., Martens, K., Atnafu, B., Chernet, T., Williamson, D., Taieb, M., 1999. The ZiwayShala lake basin system, Main Ethiopian Rift: influence of volcanism, tectonics, and climatic forcing on basin formation and sedimentation. Palaeogeography, Palaeoclimatology, Palaeoecology 150 (3-4), 135-177.

Leonardi, G., 1994. Annotated Atlas of South America Tetrapod Footprints (Devonian to Holocene). Companhia de Pesquisa de Recursos Minerais, Brasília.

Leonardi, G., Dos Santos, M.d.F.C.F., 2004. New dinosaur tracksites from the Sousa Lower Cretaceous Basin (Paraíba, Brasil). Studi Trentini di Scienze Naturali-Acta Geologica $81,5-21$.

Lockley, M.G., 1985. Vanishing tracks along Alameda Parkway: implications for Cretaceous dinosaurian paleobiology from the Dakota Group, Colorado. In Chaimberlain, C.D., Kauffman, E.G., Kitely, L.M.W., Lockley, M.G. (Eds.), A Field Guide to Environments of Deposition (and Trace Fossils) of Cretaceous Sandstones of the Western Interior. SEPM Mid Year Meeting, Colorado, pp. 131-142.

Lockley, M.G., 1986. The paleobiological and paleoenvironmental importance of dinosaur footprints. Palaios 1 (1), 37-47.

Lockley, M.G., 1987. Dinosaur footprints from the Dakota Group of Eastern Colorado (USA). Mountain Geologist 24 (4), 107-122.

Lockley, M.G., 1989. Tracks and traces: new perspectives on dinosaurian behavior, ecology and biogeography. In: Padian, K., Chure, D.J. (Eds.), The Age of Dinosaurs. Short Courses in Paleontology \#2. Paleontological Society, Knoxville, Tennessee, pp. 134-145.

Lockley, M.G., 1991. Tracking Dinosaurs: A New Look at an Ancient World. Cambridge University Press, Cambridge. 238 pp.

Lockley, M.G., 1997. The paleoecological and paleoenvironmental utility of dinosaur tracks. In: Farlow, J.O., Brett-Surman, M.K. (Eds.), The Complete Dinosaur. Indiana University Press, Bloomington, pp. 554-578.

Lockley, M.G., Conrad, K., 1989. The paleoenvironmental context, preservation and paleoecological significance of dinosaur tracksites in the western USA. In: Gillette D.D., Lockley, M.G. (Eds.), Dinosaur Tracks and Traces. Cambridge University Press, Cambridge, pp. 121-134.

Lockley, M.G., Hunt, A.P., 1995. Dinosaur Tracks and Other Fossil Footprints of the Western United States. Columbia University Press, New York.

Lockley, M.G., Matsukawa, M., 1998. Lower Cretaceous vertebrate tracksites of East Asia. New Mexico Museum of Natural History and Science Bulletin 14, 135-142.

Lockley, M.G., Pittman, J.G., 1989. The megatracksite phenomenon: implications for paleoecology, evolution and stratigraphy. Journal of Vertebrate Paleontology 9, $30 \mathrm{~A}$

Lockley, M.G., Price, N.K., 1988. The Purgatoire Valley Dinosaur Tracksite region, Southeast Colorado. Geological Society of America. Centennial Fieldguide. Colorado School of Mines. Special Publication.

Lockley, M.G., Houck, K.J., Prince, N.K., 1986. North America's largest dinosaur trackway site: implications for Morrison Formation paleoecology. Geological Society of America Bulletin 97, 1163-1176.

Lockley, M.G., Holbrook, J., Hunt, A.P., Matsukawa, M., Meyer, C.A., 1992. The dinosaur freeway: a preliminary report on the cretaceous megatracksite, Dakota Group, Rocky Mountain Front Range and High Plains, Colorado, Oklahoma and New Mexico. In: Flores, R. (Ed.), Field Trip Guidebook-Mesozoic of the Western Interior SEPM Theme Meeting, Colorado, pp. 39-54.
Lockley, M.G., Foster, J., Hunt, A., 1998. A short summary of dinosaur tracks and other fossil footprints from the Morrison Formation. Modern Geologist 23 (1-4), 277-290.

Lockley, M.G., Houck, K., Yang, S.Y., Matsukawa, M., Lim, S.K., 2006a. Dinosaurdominated footprint assemblages from the Cretaceous Jindong Formation, Hallyo Haesang National Park area, Goseong County, South Korea: evidence and implications. Cretaceous Research 27 (1), 70-101.

Lockley, M.G., Kurihara, R., Mitchell, L., 2006b. New dinosaurs and crocodile tracksites from the Cretaceous Dakota Group of the Colorado Front Range, Boulder and Jefferson Counties, Colorado. New Mexico Museum of Natural History and Science Bulletin 35, 89-94

Lucas, S.G., 1998. Global Triassic tetrapod biostratigraphy and biochronology. Palaeogeography, Palaeoclimatology, Palaeoecology 143, 347-384.

Makaske, B., 2001. Anastomosing rivers: a review of their classification, origin and sedimentary products. Earth Science Reviews 53 (3-4), 149-196.

Martín-Closas, C., Alonso-Millán, A., 1998. Estratigrafía y bioestratigrafía (Charophyta) del Cretácico Inferior en el sector occidental de la Cuenca de Cameros (Cordillera Ibérica). Revista de la Sociedad Geológica de España 11 (3-4), 253-269.

Martín-Escorza, C., 1986. Las Icnolineaciones de Dinosaurios Wealdenses de EncisoNavalsaz. Zubia 4, 33-43.

Martín-Escorza, C., 1988. Orientación de las icnitas de dinosaurios en el valle del Cidacos (La Rioja). Boletín de la Real Sociedad Española de Historia Natural (Actas) $84,32-34$.

Martín-Escorza, C., 2001. Orientación de las huellas de dinosaurios en la Sierra de Cameros. Zubia 19, 139-163.

Mas, J.R., Alonso, A., Guimerà, J., 1993. Evolución tectonosedimentaria de una cuenca extensional intraplaca: La cuenca finijurasica-eocretácica de Los Cameros (La RiojaSoria). Revista de la Sociedad Geológica de España 6 (3-4), 129-144.

Mas, R., Benito, M.I., Arribas, J., Serrano, A., Guimerà, J., Alonso, Á., Alonso-Azcárate, J., 2002. La Cuenca de Cameros: desde la extensión finijurásica-eocretácica a la inversión terciaria-implicaciones en la exploración de hidrocarburos. Zubía Monográfico 14, $9-64$.

Mas, R., Benito, M.I., Arribas, J., Serrano, A., Guimerà, J., Alonso, Á., Alonso-Azcárate, J., 2003. Geological Field Trip 11 - The Cameros Basin: From Late Jurassic-Early Cretaceous Extension to Tertiary Contractional Inversion - Implications of Hydrocarbon Exploration, AAPG International Conference and Exhibition. Total, Barcelona, Spain, pp. 1-52.

Matsukawa, M., Lockley, M.G., Hunt, A.P., 1999. Three age groups of ornithopods inferred from footprints in the mid-Cretaceous Dakota Group, eastern Colorado, North America. Palaeogeography, Palaeoclimatology, Palaeoecology 147 (1-2), 39-51.

McGlue, M.M., Scholz, C.A., Karp, T., Ongodia, B., Lezzar, K.E., 2006. Facies architecture of flexural margin lowstand delta deposits in Lake Edward, East African Rift: constraints from seismic reflection imaging. Journal of Sedimentary Research 76 (6), 942-958.

Meléndez, N., Gómez-Fernández, J.C., 2000. Continental deposits of the eastern Cameros Basin (northern Spain) during Tithonian-Berriasian time. In: Gierlowski-Kordesch, E.H., Kelts, K.R. (Eds.), Lake Basins Though Space and Time, pp. 263-278.

Meyer, C.A., 1993. A sauropod dinosaur megatracksite from the Late Jurassic of northern Switzerland. Ichnos 3 (1), 29-38.

Meyer, C.A., Hippler, D., Lockley, M.G., 2001. The Late Cretaceous vertebrate ichnofacies of Bolivia - facts and implications. VII International Symposium on Mesozoic Terrestrial Ecosystems. Asociación Paleontológica Argentina. Publicación Especial, Buenos Aires, pp. 133-138.

Milàn, J., Clemmensen, L., Bonde, N., 2004. Vertical sections through dinosaur tracks (Late Triassic lake deposits, East Greenland) - undertracks and other subsurface deformation structures revealed. Lethaia 37 (3), 285-296.

Milner, A.C., Lockley, M.G., Johnson, S.B., 2006. The story of the St. George dinosaur discovery site at Johnson Farm: an important new Lower Jurassic dinosaur tracksite from the Moenave Formation of southwestern Utah. New Mexico Museum of Natural History and Science Bulletin 37, 329-345.

Mohler, R.R., Wilkinson, M.J., Giardino, J.R., 1995. The extreme reduction of Lake Chad surface area. Input to paleoclimatic reconstructions. Geological Society of America Abstracts with Programs 27 (6), 265A

Moratalla, J.J., 2008. The story of the Cameros Basin dinosaurs (Lower Cretaceous, Spain) written in their tracks. Geophysical Research Abstracts 10 EGU2008-A06390

Moratalla, J.J., Hernán, J., 2007. Dinosaur ichnocenosis and the Cameros Basin as an oblige pass area during the Lower Cretaceous of the Iberian Plate. Journal of Vertebrate Paleontology 27 (Supplement to number 3), 119A-120A

Moratalla, J.J., Hernán, J., 2008. Implicaciones paleogeográficas de los patrones direccionales de los rastros de dinosaurios de la Cuenca de Cameros (Cretácico Inferior, España). In: Ruiz-Omeñaca, J.I., Piñuela, L., García-Ramos, J.C. (Eds.), XXIV Jornadas de la Sociedad Española de Paleontología, Colunga, pp. 41-42.

Moratalla, J.J., Sanz, J.L., 1997. Cameros Basin Megatracksite. In: Currie, P.J., Padian, K. (Eds.), Encyclopedia of Dinosaurs. Academic Press, New York, pp. 87-90.

Moratalla, J.J., Sanz, J.L., Jiménez, S., 1997a. Dinosaurios en La Rioja (Guía de yacimientos paleoicnológicos). Consejería de Educación, Cultura, Juventud y Deportes-Iberdrola, Logroño. $175 \mathrm{pp}$.

Moratalla, J.J., Sanz, J.L., Jiménez, S., 1997b. Información paleobiológica y paleoambiental inferida a partir de las icnitas de dinosaurios: problemas, límites y perspectivas. Revista Española de Paleontología 12 (2), 185-196.

Moratalla, JJ., Hernán, J., Jimenez, S., 2003. Los Cayos Dinosaur Tracksite: an overview on the Lower Cretaceous ichno-diversity of the Cameros Basin (Cornago, La Rioja Province, Spain). Ichnos 10 (2), 229-240.

Ostrom, J.H., 1972. Were some dinosaurs gregarious? Palaeogeography, Palaeoclimatology, Palaeoecology 11 (4), 287-301. 
Paik, I.S., Kim, H.J., 2006. Playa lake and sheetflood deposits of the Upper Cretaceous Jindong Formation, Korea: occurrences and palaeoenvironments. Sedimentary Geology 187 (1-2), 83-103.

Paik, I.S., Kim, H.J., Lee, Y.I., 2001. Dinosaur track-bearing deposits in the Cretaceous Jindong Formation, Korea: occurrence, palaeoenvironments and preservation. Cretaceous Research 22 (1), 79-92.

Pérez-Lorente, F., 2002. La distribución de yacimientos y de tipos de huellas de dinosaurio en la Cuenca de Cameros (La Rioja, Burgos, Soria. España). Zubía Monográfico 14, 191-210.

Pérez-Lorente, F., 2003. Icnitas de dinosaurios del Cretácico en España. In: PérezLorente, F. (Ed.), Dinosaurios y otros reptiles mesozoicos en España. Instituto de Estudios Riojanos, Logroño, pp. 49-108.

Pinheiro, L.D.M., Wilson, R.C.L., Pena dos Reis, R., Whitmarsh, R.B., Ribeiro, A., 1996. The western Iberia margin: a geophysical and geological overview. In: Whitmarsh, R.B., Sawyer, D.S., Klaus, A., Beslier, M.-O., Collins, E.S., Comas, M.C., Cornen, G., de Kaenel, E., Pinheiro, L.D.M., Gervais, E., Gibson, I.L., Harry, D.L., Hobart, M.A. Kanamatsu, T., Krawcyzk, C.M., Liu, L., Lofts, J.C., Marsaglia, K.M., Meyers, P.A., Milkert, D., Milliken, K.L., Morgan, J.K., Ramirez, P., Seifert, K.E., Shaw, T.J., Wilson, C., Yin, C., Zhao, X. (Eds.), Proceedings of the Ocean Drilling Program, Scientific Results. Texas A\&M University, Ocean Drilling Program, College Station, TX, pp. 3-23.

Platt, N.H., Wright, V.P., 1991. Lacustrine carbonates; facies models, facies distributions and hydrocarbon aspects. In: Anadón, P., Cabrera, L., Kelts, K. (Eds.), Lacustrine Facies Analysis. Blackwell Scientific Publications, pp. 57-74.

Salas, R., Casas, A., 1993. Mesozoic extensional tectonics, stratigraphy and crustal evolution during the Alpine cycle of the eastern Iberian basin. Tectonophysics 228 (1-2), 33-35.

Salas, R., Guimerà, J., Mas, R., Martín-Closas, C., Meléndez, A., Alonso, A., 2001. Evolution of the Mesozoic central Iberian Rift System and its Cainozoic inversion (Iberian Chain). In: Ziegler, P.A., Cavazza, W., Robertson, A.H.F., Crasquin-Soleau, S. (Eds.), Peri-Tethys Memoir 6: Peri-Tethyan Rift/Wrench Basins and Passive Margins. Museum National d'Histoire Naturelle, Paris, pp. 145-186.

Sanz, J.L., Moratalla, J.J., Rubio, J.L., Fuentes, C., Meijide, M., 1997. Huellas de dinosaurios de Castilla y León: Burgos y Soria. Junta de Castilla y León, Soria. 87 pp.

Schlische, R.W., Olsen, P.E., 1990. Quantitative filling model for continental extensional basins with applications to Early Mesozoic rifts of Eastern North America. Journal of Geology 98 (2), 135-155.
Schumacher, B.A., 2003. An addition to the dinosaur freeway megatracksite, Dakota Group (Upper Cretaceous), Bent County, Colorado. Ichnos 10 (2-4), 255-262.

Sibuet, J.C., Monti, S., Loubrieu, B., Maze, J.P., Srivastava, S., 2004a. Carte bathymétrique de l'Atlantique nord-est et du golfe de Gascogne: implications cinématiques. Bulletin de la Societe Geologique de France 175 (5), 429-442.

Sibuet, J.C., Srivastava, S.P., Spakman, W., 2004b. Pyrenean orogeny and plate kinematics. Journal of Geophysical Research 109, B08104. doi:10.1029/2003JB002514.

Slingerland, R., Smith, N.D., 2004. River avulsions and their deposits. Annual Review of Earth and Planetary Sciences 32 (1), 257-285.

Soto, R., Casas-Sainz, A.M., del Río, P., 2007. Geometry of half-grabens containing a midlevel viscous décollement. Basin Research 19 (3), 437-450.

Stager, J., Johnson, T., 2008. The late Pleistocene desiccation of Lake Victoria and the origin of its endemic biota. Hydrobiologia 596 (1), 5-16.

Tischer, G., 1966. Über die Wealden-Ablagerung und die Tektonik der östlichen Sierra de los Cameros in den nordwestlichen Iberischen Ketten (Spanien). Beihefte zum Geologischen Jahrbuch 44, 123-164.

Torcida, F., 2006. Restos directos de dinosaurios en Burgos (Sistema Ibérico): un balance provisional. In: Colectivo Arqueológico-Paleontológico Salense (Ed.), III Jornadas Internacionales sobre Paleontología de Dinosaurios y su Entorno, Salas de los Infantes, Burgos, pp. 105-128.

Vera, J.A., 2001. Evolution of the South Iberian Continental Margin. In: Ziegler, P.A. Cavazza, W., Robertson, A.H.F., Crasquin-Soleau, S. (Eds.), Peri-Tethys Memoir 6 : Peri-Tethyan Rift/Wrench Basins and Passive Margins. Museum National d'Histoire Naturelle, Paris, pp. 109-143.

Vergés, J., García-Senz, J., 2001. Mesozoic evolution and Cainozoic inversion of the Pyrenean Rift. In: Ziegler, P.A., Cavazza, W., Robertson, A.H.F., Crasquin-Soleau, S. (Eds.), Peri-Tethys Memoir 6: Peri-Tethyan Rift/Wrench Basins and Passive Margins. Museum National d'Histoire Naturelle, Paris, pp. 187-212.

Wilmsen, M., 2005. Stratigraphy and biofacies of the Lower Aptian of Cuchía (Cantabria, northern Spain). Journal of Iberian Geology 31 (2), 253-275.

Withjack, M.O., Schlische, R.W., Olsen, P.E., 2002. Rift-basin structure and its influence on sedimentary systems. In: Renaut, R.W., Ashley, G.M. (Eds.), Sedimentation in Continental Rifts. SEPM Special Publication. Tulsa, pp. 57-81. 